\title{
TGF- $\beta$ Signaling: A Therapeutic Target to Reinstate Regenerative Plasticity in Vascular Dementia?
}

\author{
Mahesh Kandasamy ${ }^{1,2}$, Muthuswamy Anusuyadevi ${ }^{3}$, Kiera M Aigner ${ }^{4,5}$, Michael S Unger ${ }^{4,5}$, \\ Kathrin M Kniewallner ${ }^{4,5}$, Diana M Bessa de Sousa ${ }^{4,5}$, Barbara Altendorfer ${ }^{4,5}$, Heike Mrowetz ${ }^{4,5}$, \\ Ulrich Bogdahn ${ }^{4,5,6}$, Ludwig Aigner, 4,5,*
}

${ }^{1}$ Laboratory of Stem Cells and Neuroregeneration, Department of Animal Science, School of Life Sciences, Bharathidasan University, Tiruchirappalli, Tamil Nadu, India. ${ }^{2}$ Faculty Recharge Programme, University Grants Commission (UGC-FRP), New Delhi, India. ${ }^{3}$ Molecular Gerontology Group, Department of Biochemistry, School of Life Sciences, Bharathidhasan University, Tiruchirappalli, Tamil Nadu, India. ${ }^{4}$ Institute of Molecular Regenerative Medicine, Salzburg, Paracelsus Medical University. ${ }^{5}$ Spinal Cord Injury and Tissue Regeneration Center, Salzburg, Paracelsus Medical University, Salzburg, Austria. ${ }^{6}$ Velvio GmbH, Regensburg, Germany. ${ }^{7}$ Austrian Cluster for Tissue Regeneration, Vienna, Austria

\section{[Received November 19, 2019; Revised February 16, 2020; Accepted February 22, 2020]}

\begin{abstract}
Vascular dementia (VaD) is the second leading form of memory loss after Alzheimer's disease (AD). Currently, there is no cure available. The etiology, pathophysiology and clinical manifestations of VaD are extremely heterogeneous, but the impaired cerebral blood flow (CBF) represents a common denominator of VaD. The latter might be the result of atherosclerosis, amyloid angiopathy, microbleeding and micro-strokes, together causing blood-brain barrier (BBB) dysfunction and vessel leakage, collectively originating from the consequence of hypertension, one of the main risk factors for VaD. At the histopathological level, VaD displays abnormal vascular remodeling, endothelial cell death, string vessel formation, pericyte responses, fibrosis, astrogliosis, sclerosis, microglia activation, neuroinflammation, demyelination, white matter lesions, deprivation of synapses and neuronal loss. The transforming growth factor (TGF) $\beta$ has been identified as one of the key molecular factors involved in the aforementioned various pathological aspects. Thus, targeting TGF- $\beta$ signaling in the brain might be a promising therapeutic strategy to mitigate vascular pathology and improve cognitive functions in patients with VaD. This review revisits the recent understanding of the role of TGF- $\beta$ in $\mathrm{VaD}$ and associated pathological hallmarks. It further explores the potential to modulate certain aspects of VaD pathology by targeting TGF- $\beta$ signaling.
\end{abstract}

Key words: vascular dementia, TGF- $\beta$, endothelial cells, pericytes, BBB, hippocampus, neural regeneration, oxidative stress

\section{Epidemiology of Vascular Dementia}

Dementia describes a set of clinical symptoms affecting cognitive, motor and behavioral aspects, particularly in the geriatric population [1,2]. Approximately 50 million people suffer from dementia, and its incidence doubles every two decades creating a huge socioeconomic and health care burden worldwide. Vascular Dementia (VaD) contributes to $20-40 \%$ of all dementia cases making it the second most common form of dementia after Alzheimer's disease (AD) [3]. The occurrence of $\mathrm{VaD}$ varies among populations. For example, unlike $\mathrm{AD}$, the prevalence of

*Correspondence should be addressed to: Dr. Ludwig Aigner, Institute of Molecular Regenerative Medicine, Paracelsus Medical University, Strubergasse 21, 5020 Salzburg, Austria. Email: ludwig.aigner@pmu.ac.at.

Copyright: () 2020 Kandasamy $M$ et al. This is an open-access article distributed under the terms of the Creative Commons Attribution License, which permits unrestricted use, distribution, and reproduction in any medium, provided the original author and source are credited. 
$\mathrm{VaD}$ is higher in the Asian compared to the Caucasian population [4]. However, $\mathrm{VaD}$ frequently coexists with $\mathrm{AD}$ and it is often difficult to distinguish the symptoms between $\mathrm{VaD}$ and $\mathrm{AD}$. While $\mathrm{AD}$ poses a strong gender bias towards women, the prevalence of $\mathrm{VaD}$ is higher in men most likely due to cerebrovascular risk factor being more prevalent in males [5]. Thus far, there are no curative, reparative or regenerative treatments available and therefore, development of therapy for $\mathrm{VaD}$ has become an essential but unmet need.

\section{Risk factors of Vascular Dementia}

Risk factors for $\mathrm{VaD}$ are multifactorial and include aging, illiteracy, genetic predisposition, abnormal conditions and diseases such as hypertension, stroke, diabetes, obesity, coronary infarction, atrial fibrillation, and atypical biochemical blood parameters such as high cholesterol and homocysteine levels. Various lifestyle factors such as smoking, unhealthy diet and physical inactivity have been associated with an increased risk of $\mathrm{VaD}[2,6]$ (Fig. 1). In consequence, reducing or avoiding such risk factors, if possible, is strongly recommended for the prevention of VaD. These include maintenance of healthy blood pressure, prevention or control of diabetes, smoking cessation, maintaining physical fitness and controlling blood cholesterol levels. The rapid increase in cerebrovascular diseases including stroke worldwide suggests that the currently used primary preventive actions against stroke and cardiovascular diseases have very limited efficacy, most likely due to the fact that they function on a voluntary basis with limited self-motivation [7]. This leaves a huge challenge to the scientific community to develop effective therapies to successfully treat $\mathrm{VaD}$.

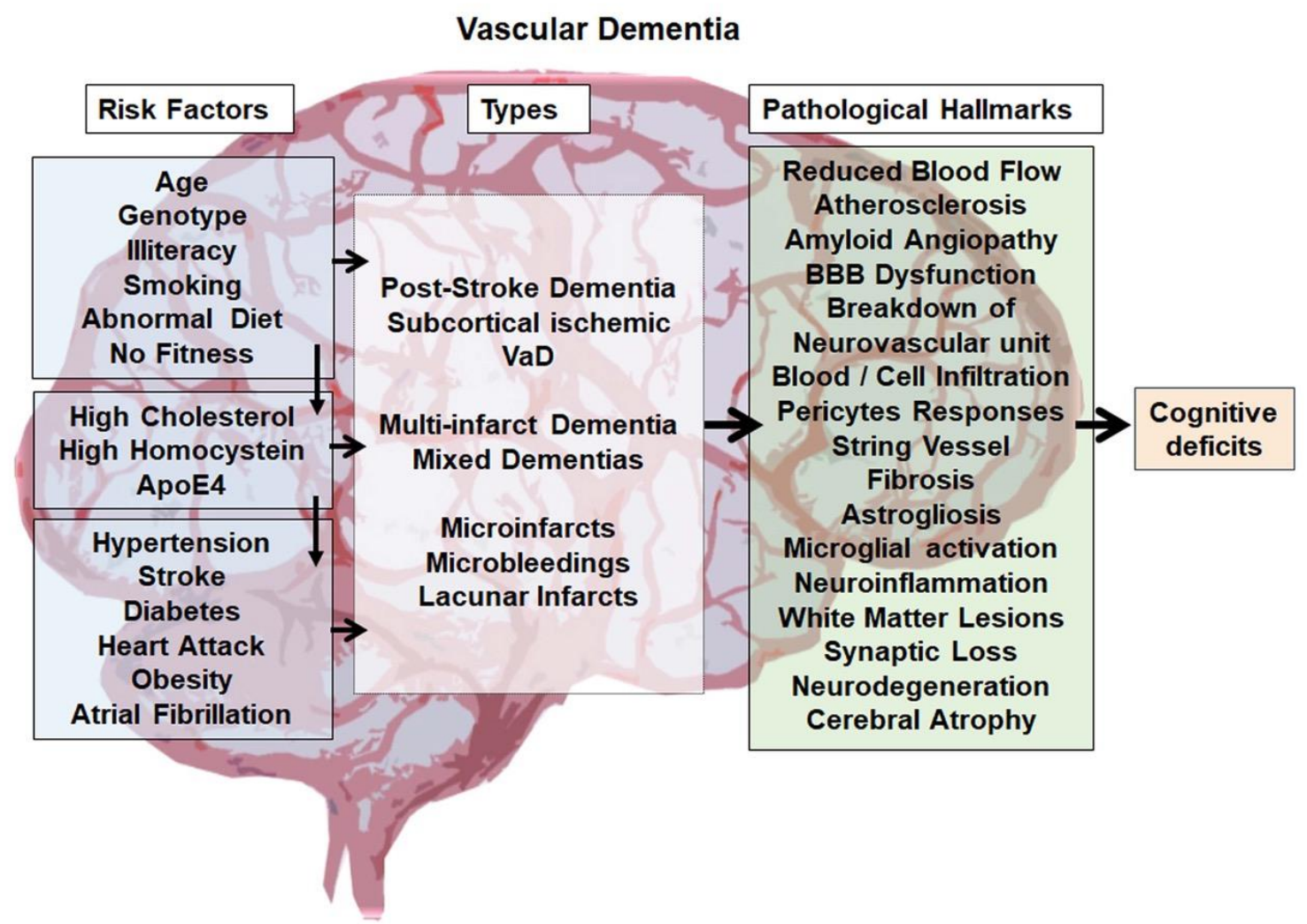

Figure 1. An overview of Vascular Dementia. The figure summarizes the possible biological and lifestyle risk factors, various forms of $\mathrm{VaD}$, pathological hallmarks of $\mathrm{VaD}$ and indicates cognitive deficit as the final outcome of the disease.

\section{Classification of Vascular Dementia}

Based on the unstructured diagnostics criteria, $\mathrm{VaD}$ has been classified into different types. In 1997, Konno S et al, proposed eight possible forms of $\mathrm{VaD}, 1$ ) multi-infarct dementia, 2) post-stroke strategic infarcts dementia, 3) multiple subcortical lacunar lesions, 4) Binswanger's disease or arteriosclerotic subcortical leukoencephalopathy, 5) mixed type of $\mathrm{VaD}$ co-occurring with types 1, 2 and 3,6) haemorrhagic lesion-induced dementia, 7) subcortical vascular dementia, and 8) mixed type of $\mathrm{VaD}$ with $\mathrm{AD}[8,9]$. The aforementioned sub-types of dementias based on vascular dysfunction include several neuropathological syndromes which are all characterized 
by a reduced cerebral blood flow (CBF) leading to cognitive dysfunctions and memory loss [2]. Some dementias occur after major and/or recurrent strokes in strategically important brain areas and are often considered a major stroke sequel based on large vessel pathology rather than an independent disease $[10,11]$. Less common forms of $\mathrm{VaD}$ are various types of vasculitis and inherited diseases that affect vessel integrity, such as CADASIL, or the three-prime repair exonuclease (TREX)-1-related thrombotic microvascular disease [1215]. The predominant form of $\mathrm{VaD}$ is based on cerebral small vessel disease, leading to vascular pathologies in deep penetrating arteries and resulting in numerous minor ischemic-hypoxic lesions (multiple lacunes) in deep cortical areas or subcortical areas [16]. Irrespective of the specific subtype, risks include atherosclerosis of cerebral arteries and cerebral amyloid angiopathy $[2,6]$ (Fig. 1).

\section{Clinical Presentation of Vascular Dementia}

In the early phase, $\mathrm{VaD}$ can be hardly differentiated from other cognitive deficits such as mild cognitive impairment $[6,17]$. As $\mathrm{VaD}$ advances, depending on the brain areas that are affected, clinical manifestations of severe cognitive deficits, loss of memory and motor disorders such as gait instability, psychiatric symptoms such as aggressiveness and depression, loss of bladder function, and increasing difficulties with daily routines become clearly evident $[1,2,6,17,18]$. Overlapping symptoms of $\mathrm{VaD}$ with other dementias and its occurrence with mixed pathologies creates a huge challenge for accurate diagnosis [17, 19]. Besides the obvious clinical symptoms, diagnosis of $\mathrm{VaD}$ requires the proof of impaired cerebral blood flow in the brain and vascular imaging such as MRI, CT, angiography and carotid ultrasound [8, 20-23].

\section{Pathological hallmarks of Vascular Dementia}

Irrespective of its origin, the pathogenesis of $\mathrm{VaD}$ is quite multifaceted. Upon a closer view, this can involve atherosclerosis, amyloid angiopathy, microbleeding and micro-stroke, blood-brain-barrier (BBB) dysfunction and leakage, infiltration and invasion of blood-derived factors such as circulating immune cells, extracellular vesicles and molecules, abnormal vascular remodeling, endothelial cell death and string vessel formation, pericyte responses, fibrosis, astrogliosis, microglia activation, oxidative stress, neuroinflammation, demyelination and white matter lesions, deprivation of synapses and neuronal loss (Fig. 1) [6, 17-19]. Spontaneous intracerebral hemorrhage can be one of the early pathological features of $\mathrm{VaD}$ [24-26]. In the lesioned or degenerative brain, BBB disruption leads to an influx of blood molecules, invasion of blood cells and microbial pathogens into the brain and is associated with inflammatory and immune responses, which can initiate multiple pathways of neurodegeneration [27]. The pathogenic mechanisms rendered by BBB breakdown leads to neuronal injury, synaptic dysfunction, loss of neuronal connectivity and neuronal loss, which have been described in neurodegenerative disorders including $\mathrm{VaD}$ [28-31].

The complex pathophysiology in $\mathrm{VaD}$ affects neuronal networks involved in behavior, intellectual process, execution and memory, ultimately leading to cognitive deficits [6,9] (Fig. 1). Considering and accepting this complexity imposes a huge challenge in drug and therapy development for $\mathrm{VaD}$. Most likely, the classical view of a drug with "single mode of action" is inappropriate for a disease like $\mathrm{VaD}$. In consequence, any kind of therapeutic strategy for the diseased brain, including $\mathrm{VaD}$, needs to address a plethora of pathological aspects in a multimodal fashion and needs collectively to include neuroprotection, plasticity, as well as regeneration in the brain. Such an approach most likely needs to be centered around the vascular niche and neurovascular unit, where the various affected cell types meet $[32,33]$.

\section{Molecular Targets of Vascular Dementia: TGF- $\beta$ as a potential candidate}

On the molecular and genetic level, a few candidates for pathogenesis in $\mathrm{VaD}$ have been discussed. For example, polymorphisms and differential expression analyses have identified apolipoprotein E (APOE), methylene-tetra hydrofolate reductase (MTHFR), paraoxonase 1 (PON1), tumor necrosis factor (TNF)-alpha, vascular endothelial growth factor (VEGF), and transforming growth factor (TGF)- $\beta 1$ as potential candidate factors involved in the pathogenesis of $\mathrm{VaD}[30,34]$. Among them, TGF- $\beta 1$ has gained a remarkable scientific interest as it plays a crucial role in angiogenesis, neuroprotection, neuroimmune functions, neural regeneration and synaptic plasticity, which are responsible for cognitive functions in the physiological state [35-38].

TGF- $\beta$ proteins (TGF- $\beta 1,2$, and 3 ) are secreted in an inactive form by various cells in various tissues and organs [35]. Thrombospondin (TSP)-1, plasmin, and matrix metalloproteinase (MMP)-2 and -9 trigger the activation process of TGF- $\beta$ [39]. Besides, the generation of reactive oxygen species (ROS) and the accumulation of an acid milieu in damaged tissues facilitate the activation of TGF- $\beta$, thereby leading to the release of TGF- $\beta$ ligands for the receptor-mediated activation of Smads [40-43]. In particular, TGF- $\beta$ induces the phosphorylation of Smad2 and Smad3 that bind to Smad4 in the cytoplasm and translocates it into the nucleus $[35,38,44]$. This 
heteromeric complex acts as a transcription factor to control the expression of various target genes. Thus, TGF$\beta$ facilitates transcriptional regulation to create a complex and synergistic higher-order signaling network in various complex biological mechanisms [35, 45] (Fig. 2).

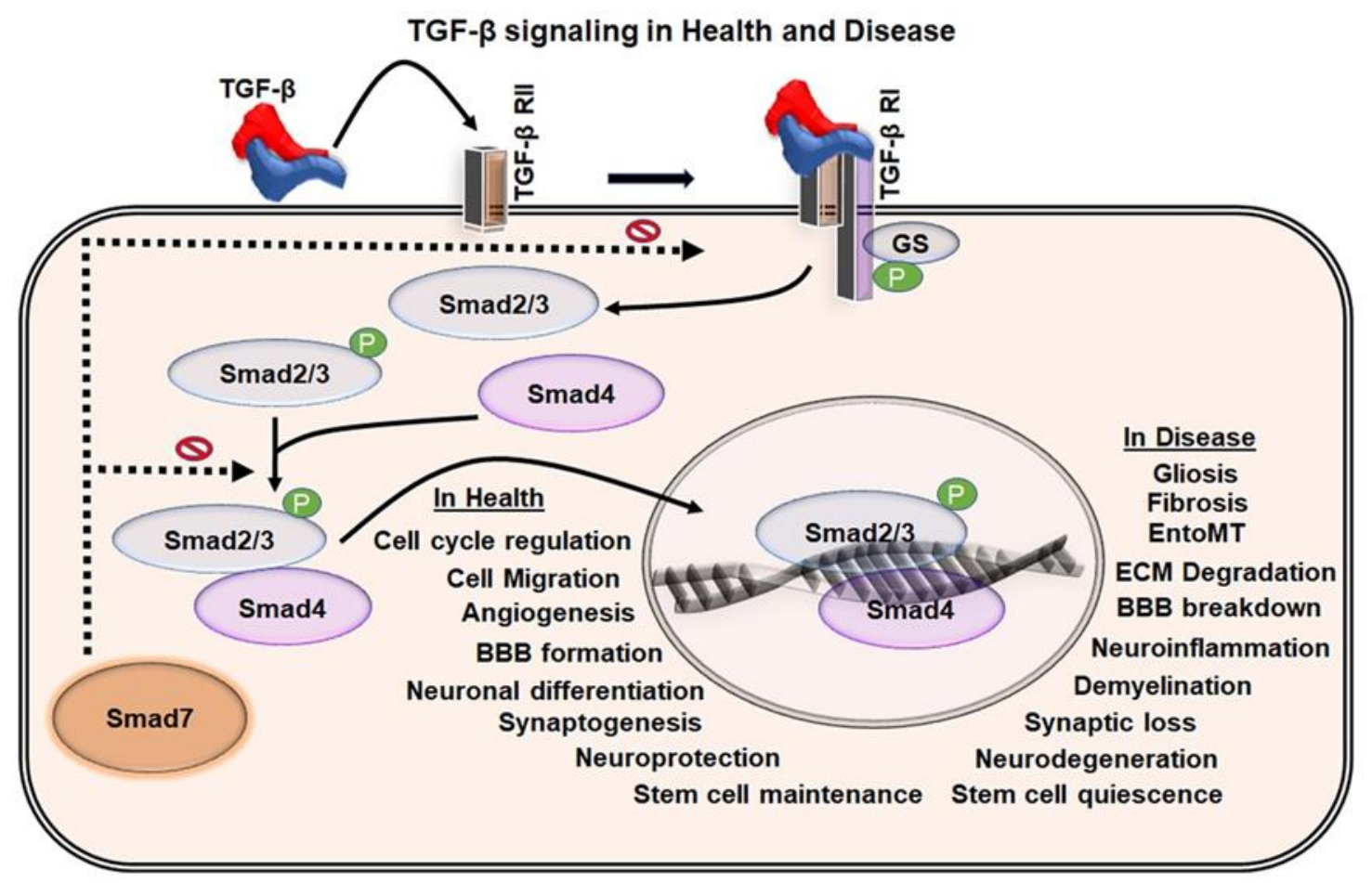

Figure 2. TGF- $\beta$ signaling in health and disease. Schematic representation of the TGF- $\beta$ mediated Smad signaling through the TGF- $\beta$ receptors. TGF- $\beta$ binds to TGF- $\beta$ receptor II, which induces the activation of TGF- $\beta$ receptor I and activates the phosphorylation of Smad2/3 in the cytoplasm. The activated Smad2/3 binds to Smad4 in the cytoplasm and mobilize into the nucleus where they act as a transcription factor. This leads to various cell-type dependent responses essential for the tissue homoeostasis and various physiological functions. Dysregulation of the TGF- $\beta$ pathway leads to abnormal cellular events and pathological hallmarks that are all part of the VaD pathology.

TGF- $\beta 1$ regulates cell proliferation, differentiation, maturation and survival of various neuronal and nonneuronal cell types in the brain $[38,46]$. Also, it regulates angiogenesis, BBB integrity, neuroinflammation, neuroplasticity and neuronal function [35, 38, 47-50]. The choroid plexus, as well as astrocytes, microglia, and endothelial cells, have been the major sources of TGF- $\beta 1$ in the brain [51-53]. In the brain, TGF- $\beta 1$ is typically elevated after acute brain injury and in chronic neurodegenerative pathologies, where it is the main driver of the astroglial scar formation, fibrosis and sclerosis [5457].

Elevated levels of TGF- $\beta 1$ in response to cerebrovascular pathologies, neurodegeneration, neuroinflammation, and neuroregenerative failure appear to be involved in the progression of dementia [34, 58-62]. Also, genetic variations in TGF- $\beta$ and TGF- $\beta$ receptors are considered as the prominent risk factors for $\mathrm{VaD}$. Thus, TGF- $\beta$ signaling is a therapeutic target candidate in various forms of cognitive disorders. Detailed information on the possible involvement of TGF- $\beta$ in $\mathrm{VaD}$ is limited. In the present review, we focus on TGF- $\beta$ and its potential role in $\mathrm{VaD}$, in particular, due to its multimodal effects in the brain and neuropathogenesis.

\section{TGF- $\beta$ and pathogenesis of $\mathrm{VaD}$}

Evidence accumulating from human genetic association studies, from expression analyses and animal experiments strongly suggest that TGF- $\beta$ plays a role in the pathogenesis of $\mathrm{VaD}$. For example, a meta-analysis of 69 studies with 4,462 cases and 11,583 controls identified polymorphisms in the TGF- $\beta 1$ gene to be associated with a higher risk for $\mathrm{VaD}$, microinfarcts, ischemic stroke and cerebral amyloid angiopathy $[34,63,64]$. Also, TGF- $\beta 1$ levels are increased in monocyte-derived macrophages, plasma, in the cerebrovascular system, as well as in the cerebrospinal fluid in patients and animal models of $\mathrm{VaD}$ 
$[60,62,65-69]$. and in hypertensive, diabetic and ischemic stroke patients [70, 71]. In CARASIL, a hereditary small vessel disease, mutations in the serine protease HTRA1 gene result in increased TGF- $\beta$ signaling, provoking multiple effects including vascular fibrosis and extracellular matrix synthesis [72, 73].

Strong evidence for the role of TGF- $\beta 1$ in $\mathrm{VaD}$ is derived from studies using mice overexpressing TGF- $\beta 1$. These mice have originally been generated by Tony Wyss-Coray and colleagues and are characterized by massive deposition of ECM and the formation of hydrocephalus [74]. This mouse model has a higher susceptibility to neuroinflammation triggered by experimental autoimmune encephalitis [75], accelerated disease progression in the context of amyotrophic lateral sclerosis (ALS) [76], severe formation of amyloid plaque pathology in the context of an AD background [69], microvascular degenerations [62], reduced level of neurogenesis [77], and most importantly, learning deficits [78]. More specifically in the context of $\mathrm{VaD}$, these mice show reduced functional vascular reactivity in the sense of a lower dilatation as well as contraction behavior in response to stimuli, capillary degenerations resulting in the formation of string vessels, vascular fibrosis and calcification [79]. Importantly, in the scenario of $\mathrm{VaD}$, the TGF- $\beta 1$ overexpressing mice show reduced CBF, which correlates with the deposition of amyloid plaques in the blood vessels [80].

\section{Cerebral blood flow and TGF- $\beta$ in VaD}

Reduced $\mathrm{CBF}$ is the hallmark of $\mathrm{VaD}$, which may be the result of very diverse conditions such as atherosclerosis, cerebral amyloid angiopathy, microbleeding, microstrokes and larger territorial stroke. Such damages typically induce a rise in TGF- $\beta 1$ levels, which locally affects neurodegenerative and neuroregenerative events. The causative role of TGF- $\beta$ in priming and development of $\mathrm{CBF}$ and $\mathrm{VaD}$ is obscure. Nevertheless, in patients with hypertension, the main risk factor for $\mathrm{VaD}$, plasma levels of TGF- $\beta 1$ are markedly increased [81] and this correlates with hypertension-induced tissue and organ damage such as nephrosclerosis and kidney diseases [82]. Thus, the observed changes in $\mathrm{CBF}$ seen in neurovascular pathologies might be strongly associated with the increased levels of TGF-mediated defects in the cellular components of the BBB.

\section{The roles of TGF- $\beta$ in BBB functions}

The BBB serves as a remarkable physical and biochemical barricade between the brain and the blood. The BBB is primarily built up by endothelial cells lining the microvessels and sealed through tight junctions. The vessel wall is ensheathed by pericytes and surrounded by end-feet of perivascular astrocytes, microglial cells, and neurons, called neurovascular unit (NVU) [83-87]. In the healthy brain, the BBB protects neurons from bloodderived factors and maintains levels of neurochemical parameters of the internal brain milieu, which are essential for neuroprotection, neuronal functioning and synaptic transmission $[84,88]$. This specialized function of the $\mathrm{BBB}$ is maintained by the establishment of a mutual trophic interference and three-dimensional vicinity between endothelial cells, pericytes and astrocytes in the brain.

The potential relationship between TGF- $\beta$ and the $\mathrm{BBB}$ is demonstrated in gene knockout studies as complete deletion of TGF- $\beta 1$, TGF- $\beta$ R 1 , TGF- $\beta$ R2, TGF$\beta R 3$ (endoglin) and of Smad4. Those resulted in defects in blood vessel formation and embryonic lethality due to an improper attachment between endothelial and mesothelial cells. Systemic inhibition of TGF- $\beta$ by soluble endoglin in pregnant rats contributes to the development of Preeclampsia, a disease condition associated with increased BBB leakage in pregnant women. Moreover, a Cre-LoxP based conditional deletion of Smad-4 specifically in brain endothelial cells resulted in BBB breakdown due to disruption in the interaction between pericytes and endothelial cells. Besides, TGF- $\beta$ contributes to the construction of basement membrane through the secretion of ECM components in endothelial cells and pericytes that are integral parts of the BBB [8991]. Moreover, the increased autocrine TGF- $\beta$ signaling in pericytes in diabetic encephalopathy induces basement membrane hypertrophy disrupting the BBB [92]. Taken together, TGF- $\beta$ plays a key role in the recruitment of pericytes and maintenance of the contact between endothelial cells and pericytes at the BBB (Fig. 3). However, the TGF- $\beta$ mediated recruitment of astrocytes to the $\mathrm{BBB}$ and the complete molecular basis of interactions among cellular components of the BBB remain largely unknown.

In the context of cancer, increased TGF- $\beta$ facilitates metastasis of tumor cells through the down-regulation of junctional adhesion and tight junction proteins upon the induction of matrix metalloproteases (MMPs) [35, 93]. Similarly, in neuroinflammatory conditions, downregulation of the expression of junctional adhesion and tight junction proteins in the blood vessel and increased expression of MMPs in association with abnormal TGF- $\beta$ signaling primes the leakage of $\mathrm{BBB}$, which in turn leads to degeneration of endothelial cells, pericytes drifting and string vessels in the neurovascular systems [94]. Based on the observation from the ablation of the TGF- $\beta$ signaling pathway in pericytes through retroviral-mediated expression of a truncated C-terminal intracellular kinase domain of TGF- $\beta$ R2, Sieczkiewicz GJ et al. have 
described that endothelial cell-specific secretion of TGF$\beta$ inhibits the mitotic activities of pericytes through the activation of pericyte contractile protein leading to the BBB breakdown [95].

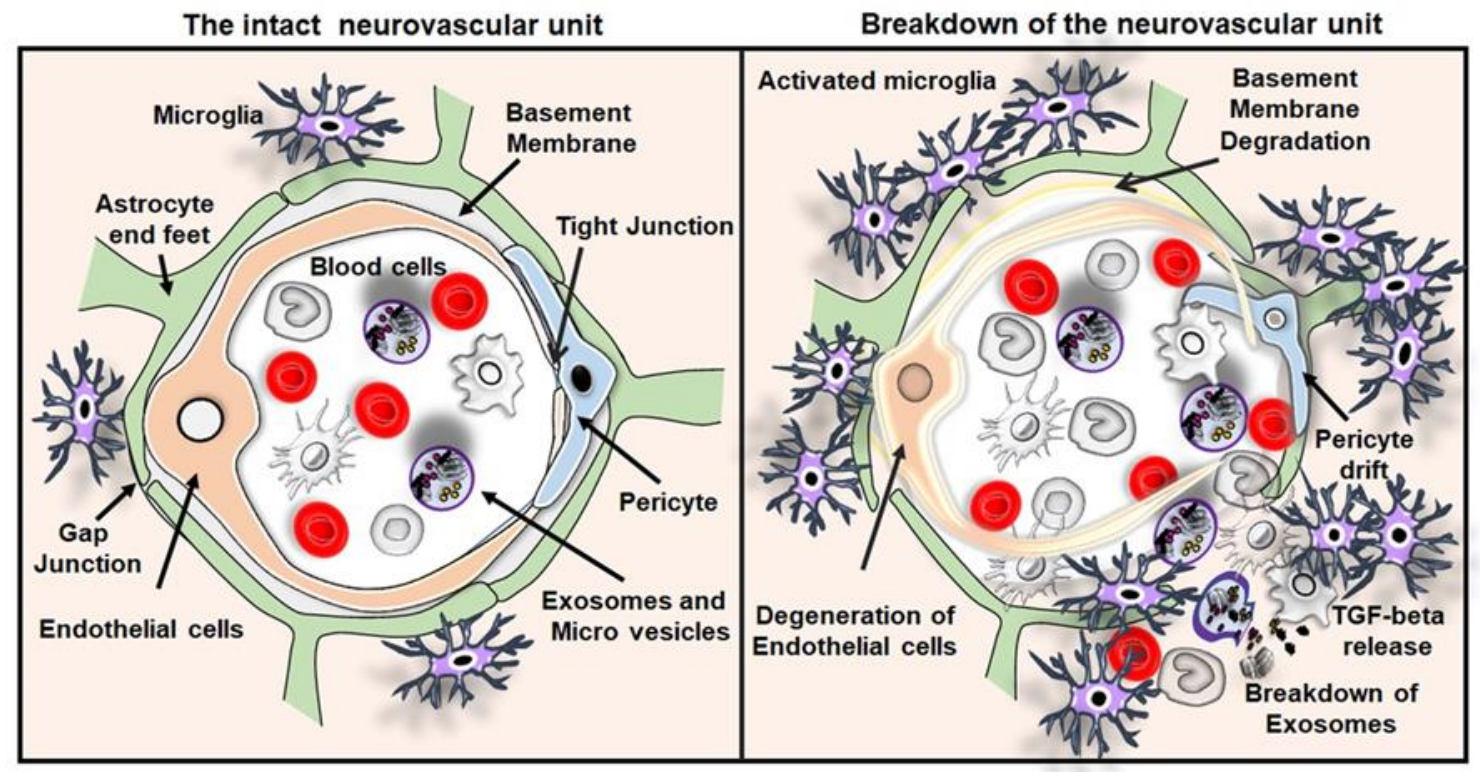

Figure 3. The intact neurovascular unit and breakdown of the neurovascular unit in VaD. Illustrations of the intact neurovascular unit that typically contains normal blood cells, endothelial cells, basement membrane ensheathed by pericytes and end feet of astrocytes in the brain. The figure also represents the breakdown of the neurovascular unit resulting from the BBB disruption, the crucial pathological hallmarks of $\mathrm{VaD}$ such as endothelial cell death and drift of pericyte. The activation of immune cells interaction between the activated microglia and peripheral blood cells leading to the release of TGF- $\beta$ and breakdown of exosomes and release of macrovesicles in the brain of subjects with VaD.

\section{Abnormal levels of TGF- $\beta$ and BBB dysfunction in VaD}

In a preclinical genetic mouse model of $\mathrm{VaD}$ with a point mutation in the NOTCH3 gene, TGF- $\beta$ signaling is disrupted, and pericyte numbers are reduced leading to BBB breakdown. Notably, endothelial-specific Smad4 deficient animals had increased BBB permeability, BBB breakdown and intracranial haemorrhages [96]. Moreover, the animal models with endothelial cellspecific depletion of TGF-receptors including endoglin have cerebrovascular defects and BBB dysfunctions [97101]. In humans, mutations in the TGF- $\beta$ receptors have been linked to hereditary haemorrhagic telangiectasia (HHT). HHT is an autosomal dominant vascular dysplasia, caused by mutations in endoglin and ALK1, which is characterized by dilated vessels and arteriovenous malformations [102]. Eventually, the transgenic model of HHT is characterized by significant structural alterations in cerebral blood vessels, pericyte drift and BBB breakdown [103]. However, the role of TGF- $\beta$ in the BBB breakdown and vessel leakage in VaD is currently not clear. While many cerebrovascular pathologies, including $\mathrm{VaD}$, have been characterized by the increased level of TGF- $\beta$, defects in its downstream pathways and impact of the crosstalk between abnormal levels of TGF- $\beta$ and other signaling mechanism needs to be considered. Future studies directed towards the potential involvement of TGF- $\beta$ in BBB dysfunction would signify the therapeutic options for $\mathrm{VaD}$.

\section{The role of TGF- $\beta$ in vascular remodeling in $\mathrm{VaD}$}

Vascular remodeling (VR) is a dynamic process of structural plasticity of blood vessels in which the blood vessel cells are constantly altered at the level of cell growth, cell migration, cell death, and at the level of production and degradation of ECM components present in the basement membrane [104-108]. This can be in response to variation in blood flow and hypertension, and also as a consequence of lesions [107, 109, 110]. Interactions between vascular cells mediate the regulation of VR through signaling of growth factors, vasoactive substances and hemodynamic stimuli [109, 111]. Endothelial cells contribute to vascular hemostasis, interact with circulating blood cells, provide resistance over the hemodynamic tension and mechanical stimuli from blood pressure, and respond to inflammation [112114]. TGF- $\beta$ signaling is one of the key pathways involved in the regulation of VR $[115,116]$. In general, 
mechanical stimuli are crucial regulators of growth as well as degeneration of endothelial cells that contribute to VR [117, 118]. Spontaneously hypertensive rats with altered hemodynamics exhibited increased levels of endothelial heparan sulfate proteoglycan (HSPG), another key component of basement membrane regulated by TGF- $\beta$-Smad signaling [119]. While TGF- $\beta 1$ deficient mice are embryonic lethal due to defects in vasculogenesis [120], in vivo induction of TGF- $\beta 1$ appears to mediate angiogenesis. TGF- $\beta$ has been reported to exert differential effects on vascular endothelial cells. In general, the formation of new capillaries from preexisting blood vessels is mediated by TGF- $\beta 1$ induced expression of endothelial cell VEGF through fibroblast growth factor (FGF-2)[47]. Recently, Schlecht et al. described that TGF- $\beta$ is required for physiological vasculogenesis in the eye, as deletion of TGF- $\beta$ R2 especially in endothelial cells of the eye results in choroidal neovascularization [121]. Moreover, in vitro experiments of cultured endothelial cells suggest that TGF- $\beta$ inhibits the mitotic activity and induces cell death of endothelial cells [122, 123]. In addition, prolonged treatment of vascular endothelial cells together with TGF$\beta$ and FGF-2 abolishes the mitogenic effect of FGF-2 on endothelial cell function and migration through the deactivation of plasminogen activator $[124,125]$. Apparently, there exists a positive feedback loop from TGF- $\beta 1$ induced VEGF expression that in turn boosts the expression of TGF- $\beta$, which results in the activation of p38 mitogen-activated protein kinase (MAPK) leading to the degeneration of endothelial cells during chronic neuroinflammation and vascular pathogenesis [126]. When endothelial cell death occurs, the basement membrane persists as empty tubes known as string or ghost vessels. Such TGF- $\beta$ induced degeneration in endothelial cells appears to induce string vessels in the brain [126], which are often associated with neurovascular pathogenesis in $\mathrm{AD}$ and $\mathrm{VaD}$ [59]. Microvessels isolated from brains of $\mathrm{AD}$ subjects with vascular pathologies are also reported to release TGF- $\beta$ [66]. In the context of cerebral amyloid angiopathy, TGF$\beta$ appears to induce the generation of amyloid- $\beta$ depositions in blood vessels. Thus, TGF- $\beta$ mediated accumulation of amyloid- $\beta$ might also be closely associated with the endothelial cell death leading to cerebrovascular pathologies in $\mathrm{VaD}[127,128]$.

Recently, endothelial to mesenchymal transition (EndoMT) has been proposed as a potential mechanism involved in VR and BBB breakdown in cerebrovascular pathologies $[129,130]$. EndoMT is a cellular process by which endothelial cells dedifferentiate into mesenchymal cells leading to degradation of vascular basement membrane and disintegration of endothelial cells [131]. Moreover, physiological properties and functions of endothelial cells are impaired, and they acquire a migratory phenotype. Notably, cardiac fibrosis, metastatic conditions, systemic sclerosis, multiple sclerosis, stroke, cerebral cavernous malformation, vein stenosis and diabetic retinopathy have been characterized by EndoMT [132-134]. Troletti et al. demonstrated that neuroinflammation-mediated TGF- $\beta$ and IL- $1 \beta$ play a key role in EndoMT in the vasculature of human post-mortem brains with multiple sclerosis and cerebrovascular abnormalities [129]. Moreover, inhibition of TGF- $\beta$ signaling by neutralizing antibodies, endothelial cellspecific Smad2/3 deletion, shRNA-mediated knockdown of Smad2 and haploinsufficiency of Smad3 minimize EndoMT $[135,136]$.Therefore, abnormal circulation of TGF- $\beta$ might contribute to VR and breakdown of BBB through EndoMT in $\mathrm{VaD}$.

\section{Pericyte responses in $\mathrm{VaD}$ and the role of TGF- $\beta$}

Pericytes are multifunctional cells which ensheath the blood vessel and contribute to the regulation of capillary diameter, vasoconstriction and vasodilation, capillary blood flow and extracellular matrix protein secretion [33, 137, 138]. Moreover, pericytes have an immunemodulatory role in the brain [139]. With reference to the origin of the pericytes, both the mesenchymal and neural crest cells have been proposed to give rise to pericytes in many organs. It has recently been reported that pericytes play important roles in the homeostasis of the brain [140142]. Pericytes are positioned within the BBB between endothelial cells, astrocytes and neurons [138]. Thus, pericytes can integrate and process signals from their adjacent cells to mediate diverse functional responses that are important for brain function in health and disease, including the regulation of the BBB permeability, angiogenesis, clearance of toxic metabolites, phagocytotic activity, capillary hemodynamic responses and neuroinflammation.

In human post-mortem $\mathrm{AD}$ brains and transgenic animal models of $\mathrm{AD}$, pericytes are dysfunctional and they undergo degeneration [143-145]. Also, levels of soluble platelet-derived growth factor receptor $\beta$ (PDGFR- $\beta$ ), a biomarker for pericyte death, are increased in cerebrospinal fluid (CSF) of subjects with mild dementia and in transgenic AD animals [138, 146, 147]. Thus, there is evidence for pericytes being involved in $\mathrm{VaD}$, although the underlying mechanisms are largely unknown. Nevertheless, a familial form of $\mathrm{VaD}$, CADASIL is associated with dysfunction of pericytes in the brain [148].

Under physiological conditions, TGF- $\beta$ regulates the proliferation and differentiation of pericytes and their attachment to endothelial cells to facilitate CBF and angiogenesis $[33,137,149,150]$. Apparently, the 
interaction between endothelial cells and pericytes leads to the expression of TGF- $\beta$ by both cell types, with differential responses to the TGF- $\beta$ activation [151-153]. In fibrosis, hypoxia, brain injury, brain metastasis, neurodegenerative conditions and cerebrovascular pathologies, microglia and astrocytes are activated and produce large amounts of TGF- $\beta 1$ [70, 74, 154, 155]. Elevated levels of TGF- $\beta$ in the brain stimulate the proliferation of pericytes and trans-differentiation of pericytes into myofibroblasts [156]. Controversial to that, Rustenhoven et al. have recently described that overexpression of TGF- $\beta$ suppresses the proliferation of pericytes and reduced the phagocytic ability of pericytes [150]. Moreover, a genetic model of pericyte depletion shows BBB disruption-mediated neuro-degeneration [157, 158]. Besides, a transgenic APOE4 mouse model has signs of BBB abnormality and neurodegeneration associated with dysfunctions of brain pericytes [159]. The aforementioned two genetic models have been shown to exhibit cognitive dysfunctions in association with abnormal TGF- $\beta$ signaling which might be speculated to result from VaD. Thus, TGF- $\beta$ mediated pericyte responses in neurocognitive disorders including $\mathrm{VaD}$ require detailed scientific investigations.

\section{Role of TGF- $\beta$ on exosomes and microvesicles in VaD}

Many physiological and pathophysiological processes are regulated by extracellular vesicles, which are involved in short and large distance intercellular communications independent of direct cell-to-cell contact [160, 161]. Extracellular vesicles contain high amounts of miRNAs and proteins originated in many different cells including peripheral endothelial cells. At present, exosomes and microvesicles have gained huge attention in neurodegenerative diseases including dementia, for example in $\mathrm{AD}$ [162-165]. Of note, in the context of $\mathrm{AD}$ and $\mathrm{VaD}$, the intermediate products of amyloid- $\beta$, such as lower molecular weight amyloid- $\beta$ oligomers and protofibrils, are transported in extracellular vesicles spreading from neuron to neuron. Those are neurotoxic and act as a source for further aggregation of amyloid- $\beta$ in the brain [165]. Interestingly, intracellular amyloid- $\beta$ is often found to be co-localized with exosomes $[166,167]$. Remarkably, mobilization of exosomes is regulated by TGF- $\beta$. For example, TGF- $\beta$ is involved in the transport of MMP2 containing exosomes in malignancy disorders [168]. Therefore, it can be speculated that the increased levels of TGF- $\beta$ in brains with $\mathrm{AD}$ and $\mathrm{VaD}$ may play a key role in transport and accumulation of amyloid- $\beta$ responsible for neurodegeneration.

\section{Neuroinflammation and astrogliosis in $\mathrm{VaD}$ and the role of TGF- $\beta$}

Neuroinflammation, like in many other neurodegenerative diseases, is one of the crucial hallmarks of $\mathrm{VaD}$ [146]. It describes a wide range of inflammatory responses within the CNS and is mediated by the production of cytokines, chemokines, and reactive oxygen species. At the cellular level, neuroinflammation involves mainly myeloid cells, i.e. microglia, monocytes, and macrophages, and other peripherally derived immune cells infiltrating the CNS, as well as astrocytes. In response to vascular injuries, microglia are the first cells to respond. Initially classified as M1 pro-inflammatory and anti-regenerative, and M2 anti-inflammatory and proregenerative, it is now clear that microglia appear in many different subtypes and phenotypes, with high plasticity and transition between the various types [169-171]. Though microglia have altered activity in $\mathrm{VaD}$ even before clinical symptoms and neuropathological hallmarks arise $[85,172]$, their precise role in $\mathrm{VaD}$ is unclear. Nevertheless, under inflammatory conditions, microglia are producers of IL-1b [173], and higher expression of IL- $1 \mathrm{~b}$ has been reported in the brain of hypertensive rats [174]. Also, microglia may contribute to $\mathrm{CBF}$ alterations and hypertensive vascular pathology in the brain [175]. Besides microglia, perivascular macrophages might be involved in particular. Monocytes are attracted to the vascular wall by vascular damage, where they differentiate into macrophages, locally secrete matrix proteins, vasculo-protective and pro-angiogenic factors as well as several other growth factors [176], promoting angiogenesis and functional recovery [177].

Neuroinflammation, in particular, microglia activity is strongly regulated by TGF- $\beta$. It seems that TGF- $\beta$ signaling maintains microglia homeostasis. For example, conditional loss of TGF- $\beta$ signaling in microglia resulted in upregulation of activation and priming markers indicative of a pro-inflammatory stage [178]. Also, TGF$\beta 1$ modulates the microglial phenotype and promotes recovery after intracerebral hemorrhage [179]. In the context of $\mathrm{VaD}, \mathrm{TGF}-\beta$ regulates microglial activity and induces resistance to hypertension. For example, removal of TGF- $\beta$ or blocking its signaling before hypertension induction accelerated hypertension progression, and supplementation of TGF- $\beta 1$ substantially suppressed neuroinflammation and generated immunosuppressive microglia [180]. In summary, TGF- $\beta$ has, in the context of neuroinflammation and microglia, anti-inflammatory and homeostatic functions (Fig. 4).

Besides monocytes and macrophages, astrocytes are involved in the pathology of $\mathrm{VaD}$. For example, astrogliosis is an acute (7 days) and chronic (3 months) response to artery occlusion in rats [181-183]. Here, in 
contrast to the effects on microglia, TGF- $\beta$ seems to have detrimental effects. For example, TGF- $\beta$ induces astrogliosis and is the main driver of gliotic scarring [74]. In the context of $\mathrm{VaD}$, TGF- $\beta$ overexpression induces a thickened vascular wall due to accumulation of extracellular matrix proteins [184]. In summary, TGF- $\beta$ plays a crucial role in neuroinflammation, in particular, in the context of microglial and astroglial cells.
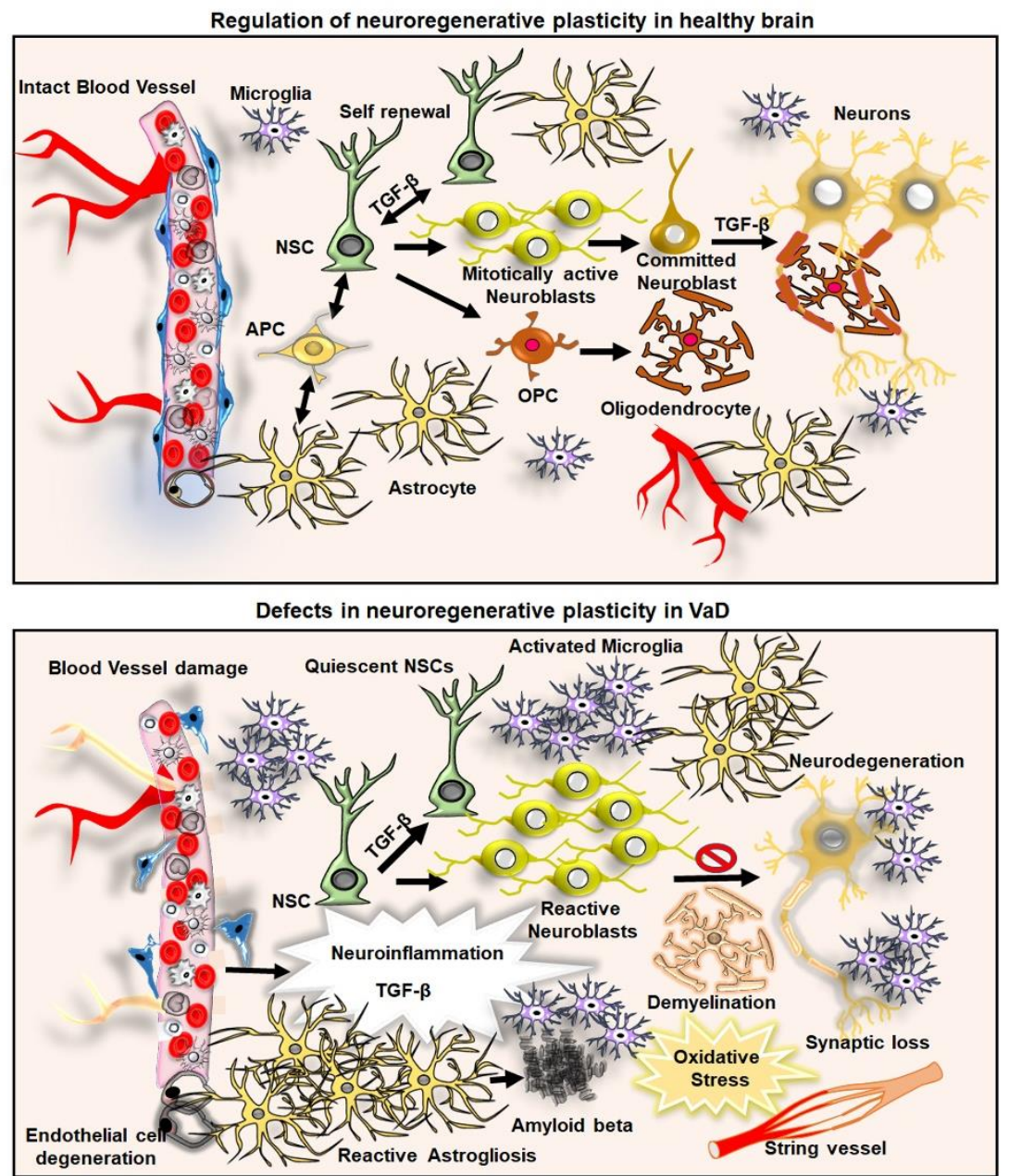

Figure 4. TGF- $\beta$ and its involvement in neuroinflammation and neurogenesis in the control brain in the context of VaD. Illustration of the regulation of adult neurogenesis by TGF- $\beta$ at the level of neural stem cell (NSC) self-renewal, transformation of neuroblasts and neuronal differentiation. The intact blood vessel, astrogenesis through astrocyte precursor cell (APS) and oligodendrogenesis from oligodendrocyte precursor cells (OPC) and resident microglial cells are indicated. In the parallel side, the figure indicates the aberrant regulation of adult neurogenesis, activated astrogliosis, microglial activation, accumulation of amyloid $\beta$, formation of string vessel, demyelination, neurodegeneration resulting from neuroinflammation mediated abnormal levels of TGF- $\beta$ in $\mathrm{VaD}$.

\section{Demyelination and white matter lesions in $\mathrm{VaD}$ and the role of TGF- $\beta$}

White matter lesions are defined by white matter hyperintensities in magnetic resonance imaging and are a hallmark of $\mathrm{VaD}$. At the cellular level, white matter lesions are characterized by myelin and oligodendrocyte loss, by axonal damages associated with axonal thinning and the accumulation of varicosities, and by loosening of the axon-oligodendrocyte adhesion [185-188]. Therefore, myelin protection and remyelination are clear targets in VaD. This is, in particular, the case in the aged brain, where remyelination is insufficient $[189,190]$.

The role of TGF- $\beta$ in de- and remyelination is still controversially discussed. For example, TGF- $\beta 1$ is associated with the progression of intracranial deep white matter lesions in humans [191]. In contrast, TGF- $\beta 1$, which is present in higher levels in the systemic environment, promotes oligodendrocyte maturation, while lower levels in circulating TGF- $\beta$ prevent remyelination in the spinal cord after toxin-induced demyelination [192]. Also, TGF- $\beta$ promoted subcortical white matter remyelination, while TGF- $\beta$ receptor deletion in oligodendroglial progenitors prevents their development into myelinating oligodendrocytes [193].

\section{Loss of synapses and neurodegeneration in $\mathrm{VaD}$ and the role of TGF- $\beta$}

Synaptic loss and neurodegeneration are the foremost neuropathological hallmarks that reflect various forms of dementia [194-196]. With reference to synaptic function, 
a wide range of proteins involved in vesicular trafficking, synapse structure and signal transduction are known. Synaptophysin, a presynaptic vesicle-specific protein is considered as a marker of synaptic integrity [197-199]. Protein expression studies on synaptic membrane preparations from various brain regions of subjects with $\mathrm{AD}$ and $\mathrm{VaD}$ revealed a reduction of synaptophysin levels in the hippocampus [200]. Postsynaptic density protein 95 (PSD-95) is a membrane-associated guanylate cyclase family of proteins located in dendritic spines and is required for synaptic plasticity $[201,202]$. The expression of PSD-95 is reduced significantly in $\mathrm{AD}$, mild cognitive impairment and VaD [203, 204]. Synaptosomalassociated protein 25 (SNAP-25) is part of the SNARE complex involved in synaptic vesicle membrane docking and fusion, and is present in the presynaptic terminal participating in exocytosis and neurotransmitter release $[205,206]$. A significant reduction in the expression of SNAP-25 is reported in AD brains, in frontotemporal dementia and $\mathrm{VaD}$ [199, 203, 207]. Drebrin (developmentally regulated brain protein), an F-actin binding protein involved in dendritic spine morphogenesis, is also drastically reduced in $\mathrm{AD}$ and mild cognitive impairment but increased in $\mathrm{VaD}$ [17, 203, 208]. The rationality of the increased level of drebrin in $\mathrm{VaD}$ is not clear but it might be a compensatory response to the ischemia related pathomechanisms caused by $\mathrm{VaD}$ [203]. The dysregulation in the expression of presynaptic and synaptic proteins that are involved in synaptic function are correlated with a significant loss of synapses in the brains of subjects with different forms of dementia.

A role of TGF- $\beta$ in synaptic protein expression is not known, but TGF- $\beta$ certainly modulates spines and spine densities. For example, the brain-specific knock down of TGF- $\beta 1$ in mice showed a reduction in the dendritic spine density and a defect in neurotransmission in the hippocampus [209]. Treatment of the sea-snail Aplysia with TGF- $\beta 1$ promotes sensorimotor synapses and reduces synaptic dysfunctions through the activation of MAPK and BDNF-mediated CREB phosphorylation $[210,211]$. Also, deficiencies in the expression of TGF- $\beta$, deletion of TGF- $\beta$ receptors and pharmacological inhibition of $S \operatorname{mad} 2 / 3$ phosphorylation induces neurodegeneration and synaptic dysfunctions $[54,178$, 212-215]. Astroglial-specific production of TGF- $\beta$ in aged transgenic mice expressing the amyloid beta precursor protein (APP) minimizes dystrophic neurites and rescues neurodegeneration [51, 216]. However, prolonged activation of microglia and thereby induced presence of an increased amount of TGF- $\beta$ in the brain is linked to the synaptic loss in $\mathrm{AD}$ and $\mathrm{VaD}$ [155, 217-220]. Also of relevance, the clinical signature of various forms of dementia is most likely linked to the synaptic dysfunctions rather than neurodegeneration [221, 222].

\section{The regulation of adult hippocampal neurogenesis by TGF- $\beta$ signaling}

Defects in hippocampal neurogenesis are proposed to contribute to cognitive deficits in dementia [223]. Recently, we provided experimental evidence for the widespread expression of the TGF- $\beta$ signaling components including Smad in the intact adult brain [38]. Immunoblotting and immunocytochemistry analyses revealed that considerable expression of TGF- $\beta \mathrm{R} 2$ is evident in the olfactory bulb cortex, striatum and cerebellum of the adult rat brain. Expression of the TGF$\beta R 2$ is relatively low in the neurogenic niches such as the hippocampus and the SVZ. However, we have noticed high expression levels of TGF- $\beta$ R1 as well as the phosphorylated form of Smad2 (pSmad2) throughout the adult brain including the neurogenic regions [38]. Further, extensive investigation of the $\mathrm{pSmad} 2$ expression in the hippocampal neurogenic niche using co-immunolabeling analysis revealed that proliferating subpopulations of Sox2 positive neural stem cells, DCX-positive neuroblasts and GFAP-positive astrocytes failed to show immunoreactivity for $\mathrm{pSmad} 2$, suggesting that they were not under TGF- $\beta$ stimulation. However, mitotically inactive NSCs, neuroblasts as well as mature neurons exhibit a high-level nuclear expression of $\mathrm{pSmad} 2$ in the adult hippocampus [38, 154]. Strikingly, glial cells such as GFAP-positive astrocytes and IBA-1 positive microglia are characterized by the expression of TGF- $\beta$ $[76,224]$. However, these immunological cells of the brain appear to be devoid of pSmad2 $[38,58]$. Thus, it suggests that glial cell-specific TGF- $\beta$ mediates paracrine signaling in the NSC niche rather than autocrine signaling in the adult brain. Further, we observed the direct effect of TGF- $\beta$ on the regulation of neurogenesis in the brain through intraventricular infusion or a transgenic system expressing TGF- $\beta$ in the brain under the doxycyclinecontrolled Ca-Calmodulin kinase promoter [38, 58, 225]. Elevation of TGF- $\beta$ reduced proliferation of NSCs but promoted the survival of neuroblasts [38]. Besides, in an in vitro study, incubation of neurosphere cultures with TGF- $\beta$ pushed the cells into the G0 phase of the cell cycle $[38,225]$. Subsequently, the above-mentioned facts were confirmed in the brains of transgenic animals that overexpress TGF- $\beta 1$ under the control of the GFAP promoter in astrocytes [77]. Taken together, it has been hypothesized that TGF- $\beta$ mediated pSmad 2 signaling is responsible for the maintenance of NSCs by inducing cellular quiescence as well as the determination of neural lineage of NSCs and neuroprotection. Moreover, as the expression of TGF- $\beta$ increases in the aging brain, it might contribute to a decline in neurogenesis [54]. There are some studies indicate that overexpression of TGF- $\beta$ can induce cell death in NSCs in the hippocampus of the adult 
brain [226]. Notably, aging brains and many neurocognitive disorders have been characterized by pathologically elevated levels of TGF- $\beta$ and defects in regenerative plasticity [227]. Hence, it has been conceptualized that impaired neurogenesis in aging and dementia can be attributed to the pathomechanism of aberrant TGF $\beta$ pathway.

\section{Regulation of neurogenesis in $\mathrm{VaD}$ and the role of TGF- $\beta$}

In an animal model of $\mathrm{VaD}$, a 2-vessel occlusion (2VO) in experimental rats mimicking chronic cerebral hypoperfusion $(\mathrm{CCH})$ [228, 229], hippocampal neurogenesis is more severely reduced in association with cognitive impairments [230]. Physical exercise rescues the deficits in hippocampal neurogenesis and cognitive functions through the BDNF-CREB pathway in $2 \mathrm{VO}$ models [231]. In another study reported by Kwon et al., the inhibition of acetylcholinesterase promotes hippocampal neurogenesis and cognitive function in $\mathrm{VaD}$ [232]. Moreover, transplantation of MSCs provided neuroprotection in the hippocampus of $2 \mathrm{VO}$ models [233]. Reports on the effects of $\mathrm{VaD}$ induced TGF- $\beta$ levels on adult neurogenesis are limited. As many animal models of AD display a vascular pathology, the regulation of adult neurogenesis by TGF- $\beta$ can be expected to be similar in $\mathrm{VaD}$ as it is described in $\mathrm{AD}[234,235]$. In corroboration with existing findings on $\mathrm{AD}$ and reports generated from experimental models of $\mathrm{VaD}$, it can be presumed that abnormal levels of TGF- $\beta$ in association with impaired neurogenesis might provide a potential mechanism for vascular abnormalities mediated defects in regenerative plasticity (Fig. 4).

Role of TGF- $\beta$ signaling in neuroprotection and neuroregeneration in neurodegenerative disorders with dementia

In many neurocognitive disorders, reactive astrogliosis, microglial activation, neuroinflammation, defects in the turnover of NSCs, reactive neuroblastosis and progressive neurodegeneration of newly generated as well as existing neurons are part of the underlying pathomechanisms of the disease [58, 236]. Among them, regenerative failure resulting from abnormal neurogenesis contributes to cognitive deficits in dementia [223]. Thus, understanding the mechanism of regeneration in the adult brain and its failures has become increasingly important. Chronic high levels of TGF- $\beta$ exacerbate pathomechanisms responsible for the development of dementia [38, 227, 234]. The expression of TGF- $\beta$ and its downstream signaling appears to be drastically increased in the brain in response to various acute brain pathologies like ischemic stroke, brain trauma and epilepsy [213, 237, 238]. In addition, the CSF of patients with AD, Huntington's disease (HD), Parkinson's disease (PD), Amyotrophic lateral sclerosis (ALS), Spinocerebellar ataxia (SCA) and Multiple system atrophy (MSA) shows increased amounts of TGF- $\beta[155$, $239,240]$. Notably, increased TGF- $\beta$ levels are correlated with the occurrence of reactive neurogenesis in postmortem brain tissue derived from many of these diseases including AD, HD and ALS [241, 242]. Moreover, many neurodegenerative disorders have been characterized by stem cell quiescence and reactive neurogenesis along with elevated levels of TGF- $\beta$ signaling during the early phases of pathogenesis [58, 154, 234, 235]. HD is an autosomal dominant neurodegenerative condition and is considered as a hereditary form of dementia, for which numerous experimental models are available [58, 243-245]. Among them, almost all transgenic rodent models of HD show elevated levels of TGF- $\beta$ signaling in association with NSC quiescence and reactive neuroblastosis, impaired neuronal differentiation and degeneration of new neurons $[58,154,227]$. The increased level of pSmads in NSCs blocks the neurogenic process at an early stage in the hippocampus of the R6/2 mouse and tgHD rat models [154]. Besides, the induced expression of TGF- $\beta$ mediated pSmad 2 increases the expression of the mutant form of huntingtin, thereby leading to neurodegeneration [227]. In addition to animal models of HD, increased levels of TGF- $\beta$ and a reduced level of neurogenesis were reported in genetic models of $\mathrm{AD}[61,246,247]$. Moreover, reduced TGF- $\beta$ R 2 expression and defects in the phosphorylation of Smad proteins are reported to be associated with an increased level of amyloidogenesis and hyper-phosphorylation of Tau in the brain of AD subjects [248-250]. Thus, available reports on the regulation of neurogenesis in response to the abnormal levels of TGF$\beta$ appears somewhat inconsistent in AD [250-252], but this may relate to the stage of the disease and degree of the pathology.

Several studies have indicated that the induction of TGF- $\beta$ during pathogenesis exerts a defensive role in preventing neurodegeneration [219]. Reduced expression of TGF- $\beta$ and deficient Smad signaling in neurons induces neurodegeneration in the terminal stage of the disease [61]. The reduced neurogenesis seen in the brains of some models of AD could provide a possible explanation for the reduction in TGF- $\beta$ mediated neurodegeneration in cognitive centers of the pathological brain. Recently, reactive neuroblasts in the diseased brain have been proposed to acquire properties of non-neuronal cells such as microglia, and thus these cells might represent a potential source of TGF- $\beta$ in pathological brains [223, $253]$. The robust activation, proliferation and circulation of microglia, reactive astrocytes and neuroblasts found in early pathogenesis tend to be diminished in the late phases 
of the diseases [227, 254]. Thus, it can be hypothesized that the overall loss of neuroblasts, non-neuronal and neuronal cells in the brain in the late phase of the disease might lead to the reduced level of TGF- $\beta$, thereby fostering neurodegeneration and memory loss.

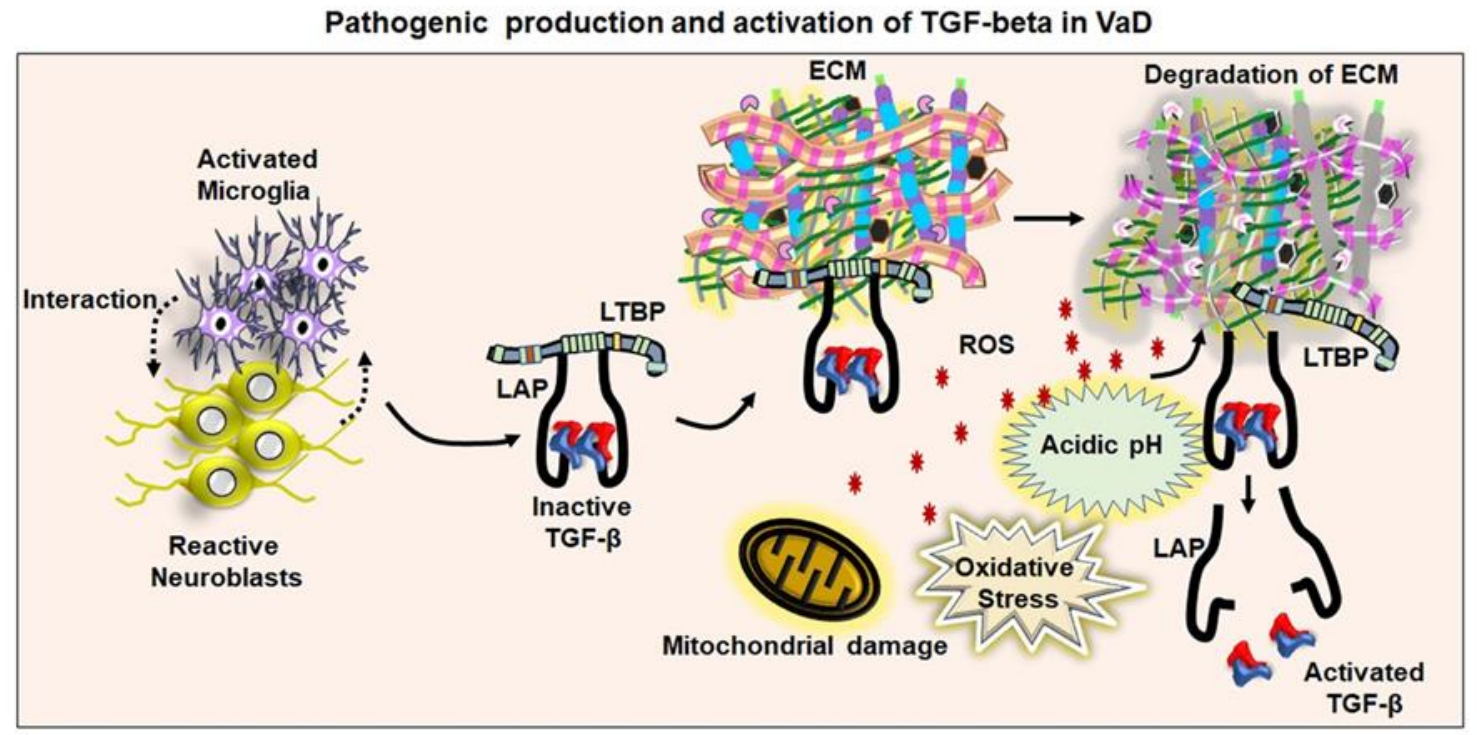

Figure 5. A proposed mechanism for TGF- $\beta$ activation in the VaD. The figure represents the proposed hypothesis that interaction between neuroblasts and activated microglial cells might lead to the production of the inactive form of the TGF- $\beta$ attached with latent transforming growth factor- $\beta$ binding protein (LTBP) through latency-associated peptide (LAP). The inactive form of TGF- $\beta$ has generally been stored in the extracellular matrix (ECM). Vascular damage upon mitochondrial defects, release of free radical and acidification of the local microenvironment might be underlying mechanisms of the pathological activation and release of TGF- $\beta$ in VaD.

\section{A proposed mechanism of TGF- $\beta$ secretion and activation in VaD}

While the potential cellular sources of the increased TGF$\beta$ levels are identified, the mechanism for the activation of TGF- $\beta$ remains unknown in neurodegenerating brains. A possible interaction between dying cells and immune cells is proposed to be involved in the production of TGF- $\beta$, which in turn can mediate the inflammatory response and oxidative stress through the generation of inflammatory factors and reactive oxygen species [255, 256] (Fig. 5). Overproduction of free radicals causes oxidative damage to molecular and subcellular components of the cell, thereby leading to cell death in many tissues [257]. Oxidative stress plays a central role in inducing neurodegeneration in many dementia cases [258]. However, the effect of free radical-mediated oxidative stress on the activation of TGF- $\beta$ has not been clearly established in neurocognitive disorders including $\mathrm{VaD}$. While the increased level of free radicals in the vasculature and reduced bioavailability of vasodilators are associated with endothelial dysfunction leading to vascular dementia, free radicals can lead to acidosis in vascular disorders in association with the degradation of
ECM [259]. As mentioned in an earlier chapter, the inactive form of TGF- $\beta$ can be activated by the freeradical mediated increased acidic condition of the tissue [260]. Thus, the increased level of free radicals might be an underlying cause for triggering the activation of TGF$\beta$ in $\mathrm{VaD}$. At the same time, in order to release the active form of TGF- $\beta$, the ECM needs to be degraded, which may result in the disruption of the cerebrovascular structure and breakdown of BBB. Thus, free radicalinduced activation of TGF- $\beta$ through the generation of acidic microenvironment could be hypothesized to play a central role in the development of VaD. Recently, Unger MS et al. provided evidence for the association of DCXexpressing T cells and microglia in the vicinity of amyloid plaques in the brain of APP-PS1 transgenic mice and human AD subjects [261]. Moreover, it could be shown that DCX-expressing immune cells exhibit indications of phagocytosis in AD brains [261]. Thus, it can be hypothesized that a potential interaction between the DCX-expressing cells and microglia may be a potential source of TGF- $\beta$ during neuropathogenesis. Eventually, the elevated TGF- $\beta$ might be an underlying factor for impaired neurogenesis responsible for memory loss in VaD. Taken together, TGF- $\beta$ signaling is an ideal 
therapeutic target to intervene in pathological associated vascular defects, neurodegeneration and promote regenerative plasticity in $\mathrm{VaD}$.

Strategies to inhibit aberrant TGF- $\beta$ signaling

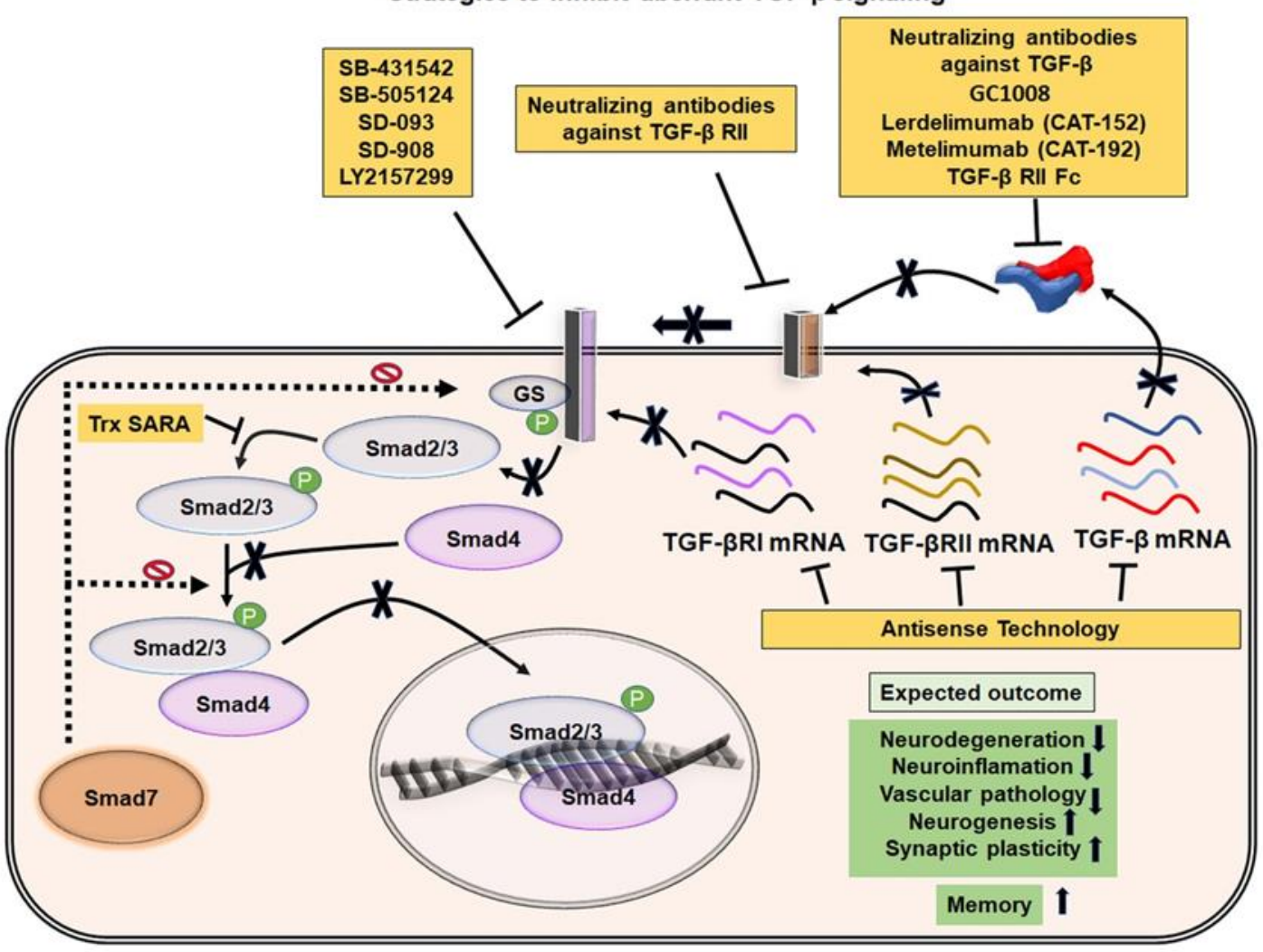

Figure 6. Possible strategies to inactivate TGF- $\beta$ signaling and expected outcomes in VaD. Illustration of possible ways to inhibit aberrant TGF- $\beta$ signaling pathways. The activities of TGF- $\beta$ and TGF- $\beta$ receptors can be neutralized using various recombinant antibodies or their translation can be blocked using specific set of antisense oligonucleotides. Different synthetic molecules that can inhibit the phosphorylation of the TGF- $\beta$ RII and Smad2/3 are also indicated. The blockade of pathogenic TGF- $\beta$ signaling has been expected to mitigate the cognitive deficits through inhibition of various neuropathogenic events and promotion of neuroregenerative plasticity in $\mathrm{VaD}$.

\section{Strategies to modulate TGF- $\beta$ signaling to mitigate pathogenesis and regenerative potentials in $\mathrm{VaD}$}

Town $\mathrm{T}$ et al. reported that the inhibition of TGF- $\beta$ signaling in peripheral immune cells by crossing the CD11c-DNR mice that express the CD11c promoterdriven dominant-negative TGF- $\beta$ receptor type 2 with $\mathrm{Tg} 2576$ mice overexpressing mAPP reduced the brain parenchymal and cerebrovascular $\beta$-amyloid deposits and improved the working memory [262]. Therefore, inhibition of overactive TGF- $\beta$ signaling has been proposed to attenuate neurovascular and neuroregenerative pathologies in $\mathrm{VaD}$.

TGF- $\beta$ can be modulated through several distinct approaches (summarized in Figure 6). The main strategies for inhibition of TGF- $\beta$ include neutralizing antibodies and recombinant fragments that block TGF- $\beta$, implementation of compounds and antisense oligonucleotides that interfere with the binding of the ligand to TGF- $\beta$ receptors, and small molecules that block intracellular phosphorylation of TGF- $\beta$ receptor 1 and Smad elements. Lerdelimumab (CAT-152) and metelimumab (CAT-192) are recombinant human IgGs generated by phage display technology that block TGF$\beta 1$ and TGF- $\beta 2$ respectively [263]. Recombinant fusion proteins containing the ectodomains of type 2 and type 3 receptors, the targeted pan-TGF- $\beta$ blocker (TTB) and soluble TGF- $\beta$ II $/ \mathrm{Fc}$ have also been used to prevent ligand binding to TGF- $\beta$ receptors [264]. The synthetic agents such as SB-431542, SB-505124, SD-093, SD-908 and LY2157299 were identified to block the catalytic activity of TGF- $\beta$ R1 [265]. Moreover, the antisense 
oligonucleotides generated against the expression of TGF- $\beta$ or the TGF- $\beta$ receptors can also be a promising approach to block TGF- $\beta$ signaling to eventually treat $\mathrm{VaD}$ at an early stage of the pathogenesis. However, the safety and efficacy of these agents need to be verified in preclinical and clinical trials. Moreover, inhibition of TGF- $\beta$ activity may elicit the risk for the anomalies in cell cycle regulation, cytoprotection, immunity and metabolism. Thus, unknown adverse effects of the inhibition of TGF- $\beta$ related to its normal biological functions and the toxic dosages of the TGF- $\beta$ agonist may not completely be excluded. Moreover, the overlapping pathophysiology between the $\mathrm{VaD}$ and $\mathrm{AD}$ needs to be dissected out, for which, the development of a valid experimental model to mimic solely the $\mathrm{VaD}$ that reflects the human situation needs to be accomplished. However, further studies are needed to appraise the discussed information and proposed ideas of this article for the most relevant clinical information.

\section{Conclusion}

There is ample scientific evidence that strongly supports that aberrant TGF- $\beta$ signaling is the main underlying mechanism for the pathogenesis of $\mathrm{VaD}$. Increasing evidence has led to TGF- $\beta$ receiving great scientific attention in recent years because it may play a critical role in the development and progression of neurovascular pathologies and neurocognitive disorders including dementia. Systemic and cerebral alteration of TGF- $\beta$ in association with the morphological changes of the cerebrovascular system and progressive cognitive disruption may serve as a potential biomarker for $\mathrm{VaD}$. In particular, the multiple aspects of the pathology of $\mathrm{VaD}$ where TGF- $\beta$ might be centrally involved makes the inhibition of TGF- $\beta$ signaling an attractive and multimodal approach to address the various aspects of VaD. Therefore, the inhibition of aberrant TGF- $\beta$ might be an ultimate therapeutic strategy for the treatment of $\mathrm{VaD}$ subjects.

\section{Acknowledgments}

This work was supported by the Austrian Science Funds (FWF) Special Research Program (SFB) F44 (F4413B23) "Cell Signaling in Chronic CNS Disorders", by the FWF Project P 31362-B34, and through funding from the European Union's Seventh Framework Program (FP7/2007-2013) under grant agreements ${ }^{\circ}$ HEALTHF2-2011-278850 (INMiND). MK has been supported by the Faculty Recharge Programme, University Grants Commission (UGC-FRP), New Delhi, India. MK would like to acknowledge a start-up grant from the UGC-FRP, a research grant (SERB-EEQ/2016/000639) and an Early
Career Research Award (SERB-ECR/2016/000741) from Science and Engineering Research Board (SERB) under the Department of Science and Technology (DST), Government of India, UGC-SAP and DST-FIST schemes for the support of the infrastructure of the Department of Animal Science, Bharathidasan University.

\section{References}

[1] Cerejeira J, Lagarto L, Mukaetova-Ladinska EB (2012). Behavioral and psychological symptoms of dementia. Front Neurol, 3:73.

[2] O'Brien JT, Thomas A (2015). Vascular dementia. Lancet, 386:1698-1706.

[3] Collaborators GBDD (2019). Global, regional, and national burden of Alzheimer's disease and other dementias, 1990-2016: a systematic analysis for the Global Burden of Disease Study 2016. Lancet Neurol, 18:88-106.

[4] Rizzi L, Rosset I, Roriz-Cruz M (2014). Global epidemiology of dementia: Alzheimer's and vascular types. Biomed Res Int, 2014:908915.

[5] Podcasy JL, Epperson CN (2016). Considering sex and gender in Alzheimer disease and other dementias. Dialogues Clin Neurosci, 18:437-446.

[6] Jellinger KA (2013). Pathology and pathogenesis of vascular cognitive impairment-a critical update. Front Aging Neurosci, 5:17.

[7] Feigin VL, Norrving B, Mensah GA (2016). Primary prevention of cardiovascular disease through population-wide motivational strategies: insights from using smartphones in stroke prevention. BMJ Glob Health, 2:e000306.

[8] Konno S, Meyer JS, Terayama Y, Margishvili GM, Mortel KF (1997). Classification, diagnosis and treatment of vascular dementia. Drugs Aging, 11:361373.

[9] Venkat P, Chopp M, Chen J (2015). Models and mechanisms of vascular dementia. Exp Neurol, 272:97-108.

[10] Guo X, Ostling S, Kern S, Johansson L, Skoog I (2018). Increased risk for dementia both before and after stroke: A population-based study in women followed over 44 years. Alzheimers Dement, 14:12531260.

[11] Pendlebury ST, Rothwell PM, Oxford Vascular S (2019). Incidence and prevalence of dementia associated with transient ischaemic attack and stroke: analysis of the population-based Oxford Vascular Study. Lancet Neurol, 18:248-258.

[12] Chabriat H, Vahedi K, Iba-Zizen MT, Joutel A, Nibbio A, Nagy TG, et al. (1995). Clinical spectrum of CADASIL: a study of 7 families. Cerebral autosomal dominant arteriopathy with subcortical infarcts and leukoencephalopathy. Lancet, 346:934-939.

[13] DiFrancesco JC, Novara F, Zuffardi O, Forlino A, Gioia R, Cossu F, et al. (2015). TREX1 C-terminal frameshift mutations in the systemic variant of retinal vasculopathy with cerebral leukodystrophy. Neurol 
Sci, 36:323-330.

[14] Joutel A, Corpechot C, Ducros A, Vahedi K, Chabriat $\mathrm{H}$, Mouton $\mathrm{P}$, et al. (1996). Notch3 mutations in CADASIL, a hereditary adult-onset condition causing stroke and dementia. Nature, 383:707-710.

[15] Richards A, van den Maagdenberg AM, Jen JC, Kavanagh D, Bertram P, Spitzer D, et al. (2007). Cterminal truncations in human 3'-5' DNA exonuclease TREX1 cause autosomal dominant retinal vasculopathy with cerebral leukodystrophy. Nat Genet, 39:1068-1070.

[16] Kalaria RN, Erkinjuntti T (2006). Small vessel disease and subcortical vascular dementia. J Clin Neurol, 2:111 .

[17] Kalaria RN (2018). The pathology and pathophysiology of vascular dementia. Neuropharmacology, 134:226-239.

[18] Iemolo F, Duro G, Rizzo C, Castiglia L, Hachinski V, Caruso C (2009). Pathophysiology of vascular dementia. Immun Ageing, 6:13.

[19] Battistin L, Cagnin A (2010). Vascular cognitive disorder. A biological and clinical overview. Neurochem Res, 35:1933-1938.

[20] Kanekar S, Poot JD (2014). Neuroimaging of vascular dementia. Radiol Clin North Am, 52:383-401.

[21] Lambert C, Zeestraten E, Williams O, Benjamin P, Lawrence AJ, Morris RG, et al. (2018). Identifying preclinical vascular dementia in symptomatic small vessel disease using MRI. Neuroimage Clin, 19:925938.

[22] Malojcic B, Giannakopoulos P, Sorond FA, Azevedo E, Diomedi M, Oblak JP, et al. (2017). Ultrasound and dynamic functional imaging in vascular cognitive impairment and Alzheimer's disease. BMC Med, $15: 27$.

[23] van Straaten EC, Scheltens P, Barkhof F (2004). MRI and CT in the diagnosis of vascular dementia. J Neurol Sci, 226:9-12.

[24] Moulin S, Labreuche J, Bombois S, Rossi C, Boulouis $\mathrm{G}$, Henon $\mathrm{H}$, et al. (2016). Dementia risk after spontaneous intracerebral haemorrhage: a prospective cohort study. Lancet Neurol, 15:820-829.

[25] Xiong XY, Liu L, Wang FX, Yang YR, Hao JW, Wang PF, et al. (2016). Toll-Like Receptor 4/MyD88Mediated Signaling of Hepcidin Expression Causing Brain Iron Accumulation, Oxidative Injury, and Cognitive Impairment After Intracerebral Hemorrhage. Circulation, 134:1025-1038.

[26] You S, Wang X, Lindley RI, Robinson T, Anderson CS, Cao Y, et al. (2017). Early Cognitive Impairment after Intracerebral Hemorrhage in the INTERACT1 Study. Cerebrovasc Dis, 44:320-324.

[27] Sweeney MD, Sagare AP, Zlokovic BV (2018). Bloodbrain barrier breakdown in Alzheimer disease and other neurodegenerative disorders. Nat Rev Neurol, 14:133-150.

[28] Ueno M, Chiba Y, Matsumoto K, Murakami R, Fujihara R, Kawauchi M, et al. (2016). Blood-brain barrier damage in vascular dementia. Neuropathology, $36: 115-124$
Wallin A, Blennow K, Fredman P, Gottfries CG, Karlsson I, Svennerholm L (1990). Blood brain barrier function in vascular dementia. Acta Neurol Scand, 81:318-322.

[30] Wallin A, Kapaki E, Boban M, Engelborghs S, Hermann DM, Huisa B, et al. (2017). Biochemical markers in vascular cognitive impairment associated with subcortical small vessel disease - A consensus report. BMC Neurol, 17:102.

[31] Zhao Z, Nelson AR, Betsholtz C, Zlokovic BV (2015). Establishment and Dysfunction of the Blood-Brain Barrier. Cell, 163:1064-1078.

[32] Demuth HU, Dijkhuizen RM, Farr TD, Gelderblom M, Horsburgh K, Iadecola C, et al. (2017). Recent progress in translational research on neurovascular and neurodegenerative disorders. Restor Neurol Neurosci, 35:87-103.

[33] Rivera FJ, Silva ME, Aigner L (2017). Editorial: The Vascular Niche in Tissue Repair: A Therapeutic Target for Regeneration. Front Cell Dev Biol, 5:88.

[34] Kim Y, Lee C (2006). The gene encoding transforming growth factor beta 1 confers risk of ischemic stroke and vascular dementia. Stroke, 37:2843-2845.

Aigner L, Bogdahn U (2008). TGF-beta in neural stem cells and in tumors of the central nervous system. Cell Tissue Res, 331:225-241.

[36] Caraci F, Battaglia G, Bruno V, Bosco P, Carbonaro V, Giuffrida ML, et al. (2011). TGF-beta1 pathway as a new target for neuroprotection in Alzheimer's disease. CNS Neurosci Ther, 17:237-249.

[37] Henrich-Noack P, Prehn JH, Krieglstein J (1996). TGF-beta 1 protects hippocampal neurons against degeneration caused by transient global ischemia. Dose-response relationship and potential neuroprotective mechanisms. Stroke, 27:1609-1614; discussion 1615.

[38] Kandasamy M, Lehner B, Kraus S, Sander PR, Marschallinger J, Rivera FJ, et al. (2014). TGF-beta signalling in the adult neurogenic niche promotes stem cell quiescence as well as generation of new neurons. J Cell Mol Med, 18:1444-1459.

[39] Gomez-Duran A, Mulero-Navarro S, Chang X, Fernandez-Salguero PM (2006). LTBP-1 blockade in dioxin receptor-null mouse embryo fibroblasts decreases TGF-beta activity: Role of extracellular proteases plasmin and elastase. J Cell Biochem, 97:380-392.

[40] Annes JP, Munger JS, Rifkin DB (2003). Making sense of latent TGFbeta activation. J Cell Sci, 116:217-224.

[41] Liu RM, Desai LP (2015). Reciprocal regulation of TGF-beta and reactive oxygen species: A perverse cycle for fibrosis. Redox Biol, 6:565-577.

[42] Lyons RM, Keski-Oja J, Moses HL (1988). Proteolytic activation of latent transforming growth factor-beta from fibroblast-conditioned medium. J Cell Biol, 106:1659-1665.

[43] Nocera M, Chu TM (1995). Characterization of latent transforming growth factor-beta from human seminal plasma. Am J Reprod Immunol, 33:282-291. 
[44] Schmierer B, Hill CS (2007). TGFbeta-SMAD signal transduction: molecular specificity and functional flexibility. Nat Rev Mol Cell Biol, 8:970-982.

[45] Luo K (2017). Signaling Cross Talk between TGFbeta/Smad and Other Signaling Pathways. Cold Spring Harb Perspect Biol, 9.

[46] Krieglstein K, Strelau J, Schober A, Sullivan A, Unsicker K (2002). TGF-beta and the regulation of neuron survival and death. J Physiol Paris, 96:25-30.

[47] Ferrari G, Cook BD, Terushkin V, Pintucci G, Mignatti P (2009). Transforming growth factor-beta 1 (TGFbeta1) induces angiogenesis through vascular endothelial growth factor (VEGF)-mediated apoptosis. J Cell Physiol, 219:449-458.

[48] Patel RK, Prasad N, Kuwar R, Haldar D, AbdulMuneer PM (2017). Transforming growth factor-beta 1 signaling regulates neuroinflammation and apoptosis in mild traumatic brain injury. Brain Behav Immun, 64:244-258.

[49] Ronaldson PT, Demarco KM, Sanchez-Covarrubias L, Solinsky CM, Davis TP (2009). Transforming growth factor-beta signaling alters substrate permeability and tight junction protein expression at the blood-brain barrier during inflammatory pain. J Cereb Blood Flow Metab, 29:1084-1098.

[50] Sanjabi S, Zenewicz LA, Kamanaka M, Flavell RA (2009). Anti-inflammatory and pro-inflammatory roles of TGF-beta, IL-10, and IL-22 in immunity and autoimmunity. Curr Opin Pharmacol, 9:447-453.

[51] Diniz LP, Tortelli V, Matias I, Morgado J, Bergamo Araujo AP, Melo HM, et al. (2017). Astrocyte Transforming Growth Factor Beta 1 Protects Synapses against Abeta Oligomers in Alzheimer's Disease Model. J Neurosci, 37:6797-6809.

[52] Flood C, Akinwunmi J, Lagord C, Daniel M, Berry M, Jackowski A, et al. (2001). Transforming growth factor-betal in the cerebrospinal fluid of patients with subarachnoid hemorrhage: titers derived from exogenous and endogenous sources. J Cereb Blood Flow Metab, 21:157-162.

[53] Merrilees MJ, Sodek J (1992). Synthesis of TGF-beta 1 by vascular endothelial cells is correlated with cell spreading. J Vasc Res, 29:376-384.

[54] Doyle KP, Cekanaviciute E, Mamer LE, Buckwalter MS (2010). TGFbeta signaling in the brain increases with aging and signals to astrocytes and innate immune cells in the weeks after stroke. J Neuroinflammation, 7:62.

[55] Gao Z, Zhu Q, Zhang Y, Zhao Y, Cai L, Shields CB, et al. (2013). Reciprocal modulation between microglia and astrocyte in reactive gliosis following the CNS injury. Mol Neurobiol, 48:690-701.

[56] Johns LD, Babcock G, Green D, Freedman M, Sriram S, Ransohoff RM (1992). Transforming growth factorbeta 1 differentially regulates proliferation and $\mathrm{MHC}$ class-II antigen expression in forebrain and brainstem astrocyte primary cultures. Brain Res, 585:229-236.

[57] Meng XM, Nikolic-Paterson DJ, Lan HY (2016). TGF-beta: the master regulator of fibrosis. Nat Rev Nephrol, 12:325-338.
[58] Kandasamy M, Reilmann R, Winkler J, Bogdahn U, Aigner L (2011). Transforming Growth Factor-Beta Signaling in the Neural Stem Cell Niche: A Therapeutic Target for Huntington's Disease. Neurol Res Int, 2011:124256.

[59] Muller K, Courtois G, Ursini MV, Schwaninger M (2017). New Insight Into the Pathogenesis of Cerebral Small-Vessel Diseases. Stroke, 48:520-527.

[60] Tarkowski E, Issa R, Sjogren M, Wallin A, Blennow $\mathrm{K}$, Tarkowski A, et al. (2002). Increased intrathecal levels of the angiogenic factors VEGF and TGF-beta in Alzheimer's disease and vascular dementia. Neurobiol Aging, 23:237-243.

[61] Tesseur I, Zou K, Esposito L, Bard F, Berber E, Can $\mathrm{JV}$, et al. (2006). Deficiency in neuronal TGF-beta signaling promotes neurodegeneration and Alzheimer's pathology. J Clin Invest, 116:3060-3069.

[62] Wyss-Coray T, Lin C, Sanan DA, Mucke L, Masliah E (2000). Chronic overproduction of transforming growth factor-betal by astrocytes promotes Alzheimer's disease-like microvascular degeneration in transgenic mice. Am J Pathol, 156:139-150.

[63] Peila R, Yucesoy B, White LR, Johnson V, Kashon ML, Wu K, et al. (2007). A TGF-betal polymorphism association with dementia and neuropathologies: the HAAS. Neurobiol Aging, 28:1367-1373.

[64] Sun JH, Tan L, Wang HF, Tan MS, Tan L, Li JQ, et al. (2015). Genetics of Vascular Dementia: Systematic Review and Meta-Analysis. J Alzheimers Dis, 46:611629.

[65] Di Rosa M, Dell'Ombra N, Zambito AM, Malaguarnera M, Nicoletti F, Malaguarnera L (2006). Chitotriosidase and inflammatory mediator levels in Alzheimer's disease and cerebrovascular dementia. Eur J Neurosci, 23:2648-2656.

[66] Grammas P, Ovase R (2002). Cerebrovascular transforming growth factor-beta contributes to inflammation in the Alzheimer's disease brain. Am J Pathol, 160:1583-1587.

[67] Malaguarnera L, Motta M, Di Rosa M, Anzaldi M, Malaguarnera M (2006). Interleukin-18 and transforming growth factor-beta 1 plasma levels in Alzheimer's disease and vascular dementia. Neuropathology, 26:307-312.

[68] Trigiani LJ, Hamel E (2017). An endothelial link between the benefits of physical exercise in dementia. J Cereb Blood Flow Metab, 37:2649-2664.

[69] Wyss-Coray T, Masliah E, Mallory M, McConlogue L, Johnson-Wood K, Lin C, et al. (1997). Amyloidogenic role of cytokine TGF-betal in transgenic mice and in Alzheimer's disease. Nature, 389:603-606.

[70] Krupinski J, Kumar P, Kumar S, Kaluza J (1996). Increased expression of TGF-beta 1 in brain tissue after ischemic stroke in humans. Stroke, 27:852-857.

[71] Peterson MC (2005). Circulating transforming growth factor beta-1: a partial molecular explanation for associations between hypertension, diabetes, obesity, smoking and human disease involving fibrosis. Med Sci Monit, 11:RA229-232.

[72] Beaufort N, Scharrer E, Kremmer E, Lux V, Ehrmann 
M, Huber R, et al. (2014). Cerebral small vessel disease-related protease HtrA1 processes latent TGFbeta binding protein 1 and facilitates TGF-beta signaling. Proc Natl Acad Sci U S A, 111:16496-16501. [73] Yamamoto Y, Craggs L, Baumann M, Kalimo H, Kalaria RN (2011). Review: molecular genetics and pathology of hereditary small vessel diseases of the brain. Neuropathol Appl Neurobiol, 37:94-113.

[74] Wyss-Coray T, Feng L, Masliah E, Ruppe MD, Lee HS, Toggas SM, et al. (1995). Increased central nervous system production of extracellular matrix components and development of hydrocephalus in transgenic mice overexpressing transforming growth factor-beta 1. Am J Pathol, 147:53-67.

[75] Wyss-Coray T, Borrow P, Brooker MJ, Mucke L (1997). Astroglial overproduction of TGF-beta 1 enhances inflammatory central nervous system disease in transgenic mice. J Neuroimmunol, 77:45-50.

[76] Endo F, Komine O, Fujimori-Tonou N, Katsuno M, Jin S, Watanabe S, et al. (2015). Astrocyte-derived TGFbeta1 accelerates disease progression in ALS mice by interfering with the neuroprotective functions of microglia and T cells. Cell Rep, 11:592-604.

[77] Buckwalter MS, Yamane M, Coleman BS, Ormerod BK, Chin JT, Palmer T, et al. (2006). Chronically increased transforming growth factor-betal strongly inhibits hippocampal neurogenesis in aged mice. Am J Pathol, 169:154-164.

[78] Martinez-Canabal A, Wheeler AL, Sarkis D, Lerch JP, Lu WY, Buckwalter MS, et al. (2013). Chronic overexpression of TGFbeta1 alters hippocampal structure and causes learning deficits. Hippocampus, 23:11981211.

[79] Tong XK, Hamel E (2015). Simvastatin restored vascular reactivity, endothelial function and reduced string vessel pathology in a mouse model of cerebrovascular disease. J Cereb Blood Flow Metab, 35:512-520.

[80] Gaertner RF, Wyss-Coray T, Von Euw D, Lesne S, Vivien D, Lacombe P (2005). Reduced brain tissue perfusion in TGF-beta 1 transgenic mice showing Alzheimer's disease-like cerebrovascular abnormalities. Neurobiol Dis, 19:38-46.

[81] Derhaschnig U, Shehata M, Herkner H, Bur A, Woisetschlager C, Laggner AN, et al. (2002). Increased levels of transforming growth factor-beta 1 in essential hypertension. Am J Hypertens, 15:207-211. August P, Suthanthiran M (2006). Transforming growth factor beta signaling, vascular remodeling, and hypertension. N Engl J Med, 354:2721-2723.

[83] Brown LS, Foster CG, Courtney JM, King NE, Howells DW, Sutherland BA (2019). Pericytes and Neurovascular Function in the Healthy and Diseased Brain. Front Cell Neurosci, 13:282.

[84] Daneman R, Prat A (2015). The blood-brain barrier. Cold Spring Harb Perspect Biol, 7:a020412.

[85] Iadecola C (2017). The Neurovascular Unit Coming of Age: A Journey through Neurovascular Coupling in Health and Disease. Neuron, 96:17-42.

[86] Muoio V, Persson PB, Sendeski MM (2014). The neurovascular unit - concept review. Acta Physiol (Oxf), 210:790-798.

[87] Obermeier B, Daneman R, Ransohoff RM (2013). Development, maintenance and disruption of the blood-brain barrier. Nat Med, 19:1584-1596.

[88] Ballabh P, Braun A, Nedergaard M (2004). The bloodbrain barrier: an overview: structure, regulation, and clinical implications. Neurobiol Dis, 16:1-13.

[89] Baeten KM, Akassoglou K (2011). Extracellular matrix and matrix receptors in blood-brain barrier formation and stroke. Dev Neurobiol, 71:1018-1039.

[90] Blanchette M, Daneman R (2015). Formation and maintenance of the BBB. Mech Dev, 138 Pt 1:8-16.

[91] Whitelock JM, Melrose J, Iozzo RV (2008). Diverse cell signaling events modulated by perlecan. Biochemistry, 47:11174-11183.

[92] Shimizu F, Sano Y, Tominaga O, Maeda T, Abe MA, Kanda T (2013). Advanced glycation end-products disrupt the blood-brain barrier by stimulating the release of transforming growth factor-beta by pericytes and vascular endothelial growth factor and matrix metalloproteinase- 2 by endothelial cells in vitro. Neurobiol Aging, 34:1902-1912.

Perera M, Tsang CS, Distel RJ, Lacy JN, OhnoMachado L, Ricchiuti V, et al. (2010). TGF-beta1 interactome: metastasis and beyond. Cancer Genomics Proteomics, 7:217-229.

[94] Winkler EA, Bell RD, Zlokovic BV (2011). Lack of Smad or Notch leads to a fatal game of brain pericyte hopscotch. Dev Cell, 20:279-280.

[95] Sieczkiewicz GJ, Herman IM (2003). TGF-beta 1 signaling controls retinal pericyte contractile protein expression. Microvasc Res, 66:190-196.

[96] Li F, Lan Y, Wang Y, Wang J, Yang G, Meng F, et al. (2011). Endothelial Smad4 maintains cerebrovascular integrity by activating $\mathrm{N}$-cadherin through cooperation with Notch. Dev Cell, 20:291-302.

[97] Carvalho RL, Itoh F, Goumans MJ, Lebrin F, Kato M, Takahashi S, et al. (2007). Compensatory signalling induced in the yolk sac vasculature by deletion of TGFbeta receptors in mice. J Cell Sci, 120:4269-4277.

[98] Garrido-Martin EM, Nguyen HL, Cunningham TA, Choe SW, Jiang Z, Arthur HM, et al. (2014). Common and distinctive pathogenetic features of arteriovenous malformations in hereditary hemorrhagic telangiectasia 1 and hereditary hemorrhagic telangiectasia 2 animal models--brief report. Arterioscler Thromb Vasc Biol, 34:2232-2236.

[99] Mahmoud M, Allinson KR, Zhai Z, Oakenfull R, Ghandi P, Adams RH, et al. (2010). Pathogenesis of arteriovenous malformations in the absence of endoglin. Circ Res, 106:1425-1433.

[100] Mahmoud M, Upton PD, Arthur HM (2011). Angiogenesis regulation by TGFbeta signalling: clues from an inherited vascular disease. Biochem Soc Trans, 39:1659-1666.

[101] Tual-Chalot S, Mahmoud M, Allinson KR, Redgrave RE, Zhai Z, Oh SP, et al. (2014). Endothelial depletion of Acvrll in mice leads to arteriovenous malformations associated with reduced endoglin 
expression. PLoS One, 9:e98646.

[102] Fernandez LA, Sanz-Rodriguez F, Blanco FJ, Bernabeu C, Botella LM (2006). Hereditary hemorrhagic telangiectasia, a vascular dysplasia affecting the TGF-beta signaling pathway. Clin Med Res, 4:66-78.

[103] Thalgott J, Dos-Santos-Luis D, Lebrin F (2015). Pericytes as targets in hereditary hemorrhagic telangiectasia. Front Genet, 6:37.

[104] Gibbons GH, Dzau VJ (1994). The emerging concept of vascular remodeling. N Engl J Med, 330:1431-1438.

[105] Gutierrez J, Goldman J, Dwork AJ, Elkind MS, Marshall RS, Morgello S (2015). Brain arterial remodeling contribution to nonembolic brain infarcts in patients with HIV. Neurology, 85:1139-1145.

[106] Mulvany MJ, Baumbach GL, Aalkjaer C, Heagerty AM, Korsgaard N, Schiffrin EL, et al. (1996). Vascular remodeling. Hypertension, 28:505-506.

[107] Renna NF, de Las Heras N, Miatello RM (2013). Pathophysiology of vascular remodeling in hypertension. Int J Hypertens, 2013:808353.

[108] van Varik BJ, Rennenberg RJ, Reutelingsperger CP, Kroon AA, de Leeuw PW, Schurgers LJ (2012). Mechanisms of arterial remodeling: lessons from genetic diseases. Front Genet, 3:290.

[109] Intengan HD, Schiffrin EL (2001). Vascular remodeling in hypertension: roles of apoptosis, inflammation, and fibrosis. Hypertension, 38:581-587.

[110] Schiffrin EL (2012). Vascular remodeling in hypertension: mechanisms and treatment. Hypertension, 59:367-374.

[111] Cowan DB, Langille BL (1996). Cellular and molecular biology of vascular remodeling. Curr Opin Lipidol, 7:94-100.

[112] Cines DB, Pollak ES, Buck CA, Loscalzo J, Zimmerman GA, McEver RP, et al. (1998). Endothelial cells in physiology and in the pathophysiology of vascular disorders. Blood, 91:3527-3561.

[113] Onat D, Brillon D, Colombo PC, Schmidt AM (2011). Human vascular endothelial cells: a model system for studying vascular inflammation in diabetes and atherosclerosis. Curr Diab Rep, 11:193-202.

[114] Rajendran P, Rengarajan T, Thangavel J, Nishigaki Y, Sakthisekaran D, Sethi G, et al. (2013). The vascular endothelium and human diseases. Int $\mathrm{J}$ Biol Sci, 9:1057-1069.

[115] August P, Leventhal B, Suthanthiran M (2000). Hypertension-induced organ damage in African Americans: transforming growth factor-beta(1) excess as a mechanism for increased prevalence. Curr Hypertens Rep, 2:184-191.

[116] Ryan ST, Koteliansky VE, Gotwals PJ, Lindner V (2003). Transforming growth factor-beta-dependent events in vascular remodeling following arterial injury. J Vasc Res, 40:37-46.

[117] Butcher JT, Nerem RM (2007). Valvular endothelial cells and the mechanoregulation of valvular pathology. Philos Trans R Soc Lond B Biol Sci, 362:1445-1457. [118] Poduri A, Chang AH, Raftrey B, Rhee S, Van M, Red-
Horse K (2017). Endothelial cells respond to the direction of mechanical stimuli through SMAD signaling to regulate coronary artery size. Development, 144:3241-3252.

[119] Baker AB, Ettenson DS, Jonas M, Nugent MA, Iozzo RV, Edelman ER (2008). Endothelial cells provide feedback control for vascular remodeling through a mechanosensitive autocrine TGF-beta signaling pathway. Circ Res, 103:289-297.

[120] Dickson MC, Martin JS, Cousins FM, Kulkarni AB, Karlsson S, Akhurst RJ (1995). Defective haematopoiesis and vasculogenesis in transforming growth factor-beta 1 knock out mice. Development, 121:1845-1854.

[121] Schlecht A, Leimbeck SV, Jagle H, Feuchtinger A, Tamm ER, Braunger BM (2017). Deletion of Endothelial Transforming Growth Factor-beta Signaling Leads to Choroidal Neovascularization. Am J Pathol, 187:2570-2589.

[122] Leksa V, Godar S, Schiller HB, Fuertbauer E, Muhammad A, Slezakova K, et al. (2005). TGF-betainduced apoptosis in endothelial cells mediated by M6P/IGFII-R and mini-plasminogen. J Cell Sci, 118:4577-4586.

[123] Pollman MJ, Naumovski L, Gibbons GH (1999). Vascular cell apoptosis: cell type-specific modulation by transforming growth factor-betal in endothelial cells versus smooth muscle cells. Circulation, 99:2019-2026.

[124] Pepper MS, Belin D, Montesano R, Orci L, Vassalli JD (1990). Transforming growth factor-beta 1 modulates basic fibroblast growth factor-induced proteolytic and angiogenic properties of endothelial cells in vitro. $\mathrm{J}$ Cell Biol, 111:743-755.

[125] Saksela O, Moscatelli D, Rifkin DB (1987). The opposing effects of basic fibroblast growth factor and transforming growth factor beta on the regulation of plasminogen activator activity in capillary endothelial cells. J Cell Biol, 105:957-963.

[126] Ferrari G, Terushkin V, Wolff MJ, Zhang X, Valacca C, Poggio P, et al. (2012). TGF-betal induces endothelial cell apoptosis by shifting VEGF activation of p38(MAPK) from the prosurvival p38beta to proapoptotic p38alpha. Mol Cancer Res, 10:605-614.

[127] Sutton AB, Canfield AE, Schor SL, Grant ME, Schor AM (1991). The response of endothelial cells to TGF beta-1 is dependent upon cell shape, proliferative state and the nature of the substratum. J Cell Sci, 99 ( Pt 4):777-787.

[128] Thomas T, McLendon C, Sutton ET, Thomas G (1997). Cerebrovascular endothelial dysfunction mediated by beta-amyloid. Neuroreport, 8:1387-1391.

[129] Derada Troletti C, Fontijn RD, Gowing E, Charabati M, van Het Hof B, Didouh I, et al. (2019). Inflammation-induced endothelial to mesenchymal transition promotes brain endothelial cell dysfunction and occurs during multiple sclerosis pathophysiology. Cell Death Dis, 10:45.

[130] Kovacic JC, Dimmeler S, Harvey RP, Finkel T, Aikawa E, Krenning G, et al. (2019). Endothelial to 
Mesenchymal Transition in Cardiovascular Disease: JACC State-of-the-Art Review. J Am Coll Cardiol, 73:190-209.

[131] Piera-Velazquez S, Li Z, Jimenez SA (2011). Role of endothelial-mesenchymal transition (EndoMT) in the pathogenesis of fibrotic disorders. Am J Pathol, 179:1074-1080.

[132] Good RB, Gilbane AJ, Trinder SL, Denton CP, Coghlan G, Abraham DJ, et al. (2015). Endothelial to Mesenchymal Transition Contributes to Endothelial Dysfunction in Pulmonary Arterial Hypertension. Am J Pathol, 185:1850-1858.

[133] Krizbai IA, Gasparics A, Nagyoszi P, Fazakas C, Molnar J, Wilhelm I, et al. (2015). Endothelialmesenchymal transition of brain endothelial cells: possible role during metastatic extravasation. PLoS One, 10:e0123845.

[134] Man S, Sanchez Duffhues G, Ten Dijke P, Baker D (2019). The therapeutic potential of targeting the endothelial-to-mesenchymal transition. Angiogenesis, 22:3-13.

[135] Cooley BC, Nevado J, Mellad J, Yang D, St Hilaire C, Negro A, et al. (2014). TGF-beta signaling mediates endothelial-to-mesenchymal transition (EndMT) during vein graft remodeling. Sci Transl Med, 6:227ra234

[136] Pardali E, Sanchez-Duffhues G, Gomez-Puerto MC, Ten Dijke P (2017). TGF-beta-Induced EndothelialMesenchymal Transition in Fibrotic Diseases. Int J Mol Sci, 18.

[137] Rucker HK, Wynder HJ, Thomas WE (2000). Cellular mechanisms of CNS pericytes. Brain Res Bull, 51:363-369.

[138] Sweeney MD, Ayyadurai S, Zlokovic BV (2016). Pericytes of the neurovascular unit: key functions and signaling pathways. Nat Neurosci, 19:771-783.

[139] Navarro R, Compte M, Alvarez-Vallina L, Sanz L (2016). Immune Regulation by Pericytes: Modulating Innate and Adaptive Immunity. Front Immunol, 7:480.

[140] Ando K, Fukuhara S, Izumi N, Nakajima H, Fukui H, Kelsh RN, et al. (2016). Clarification of mural cell coverage of vascular endothelial cells by live imaging of zebrafish. Development, 143:1328-1339.

[141] Yamamoto S, Muramatsu M, Azuma E, Ikutani M, Nagai Y, Sagara H, et al. (2017). A subset of cerebrovascular pericytes originates from mature macrophages in the very early phase of vascular development in CNS. Sci Rep, 7:3855.

[142] Yamazaki T, Mukouyama YS (2018). Tissue Specific Origin, Development, and Pathological Perspectives of Pericytes. Front Cardiovasc Med, 5:78.

[143] Sagare AP, Bell RD, Zhao Z, Ma Q, Winkler EA, Ramanathan A, et al. (2013). Pericyte loss influences Alzheimer-like neurodegeneration in mice. Nat Commun, 4:2932.

[144] Sengillo JD, Winkler EA, Walker CT, Sullivan JS, Johnson M, Zlokovic BV (2013). Deficiency in mural vascular cells coincides with blood-brain barrier disruption in Alzheimer's disease. Brain Pathol, 23:303-310.
[145] Verbeek MM, de Waal RM, Schipper JJ, Van Nostrand WE (1997). Rapid degeneration of cultured human brain pericytes by amyloid beta protein. J Neurochem, 68:1135-1141.

[146] Cipollini V, Troili F, Giubilei F (2019). Emerging Biomarkers in Vascular Cognitive Impairment and Dementia: From Pathophysiological Pathways to Clinical Application. Int J Mol Sci, 20.

[147] Nation DA, Sweeney MD, Montagne A, Sagare AP, D'Orazio LM, Pachicano M, et al. (2019). Blood-brain barrier breakdown is an early biomarker of human cognitive dysfunction. Nat Med, 25:270-276.

[148] Ghosh M, Balbi M, Hellal F, Dichgans M, Lindauer U, Plesnila N (2015). Pericytes are involved in the pathogenesis of cerebral autosomal dominant arteriopathy with subcortical infarcts and leukoencephalopathy. Ann Neurol, 78:887-900.

[149] Geevarghese A, Herman IM (2014). Pericyteendothelial crosstalk: implications and opportunities for advanced cellular therapies. Transl Res, 163:296306.

[150] Rustenhoven J, Aalderink M, Scotter EL, Oldfield RL, Bergin PS, Mee EW, et al. (2016). TGF-beta1 regulates human brain pericyte inflammatory processes involved in neurovasculature function. $\mathrm{J}$ Neuroinflammation, 13:37.

[151] Hirschi KK, Rohovsky SA, D'Amore PA (1998). PDGF, TGF-beta, and heterotypic cell-cell interactions mediate endothelial cell-induced recruitment of $10 \mathrm{~T} 1 / 2$ cells and their differentiation to a smooth muscle fate. J Cell Biol, 141:805-814.

[152] Jo DH, Kim JH, Heo JI, Kim JH, Cho CH (2013). Interaction between pericytes and endothelial cells leads to formation of tight junction in hyaloid vessels. Mol Cells, 36:465-471.

[153] Ramsauer M, D'Amore PA (2007). Contextual role for angiopoietins and TGFbetal in blood vessel stabilization. J Cell Sci, 120:1810-1817.

[154] Kandasamy M, Couillard-Despres S, Raber KA, Stephan M, Lehner B, Winner B, et al. (2010). Stem cell quiescence in the hippocampal neurogenic niche is associated with elevated transforming growth factor-beta signaling in an animal model of Huntington disease. J Neuropathol Exp Neurol, 69:717-728.

[155] Peters S, Zitzelsperger E, Kuespert S, Iberl S, Heydn R, Johannesen S, et al. (2017). The TGF-beta System As a Potential Pathogenic Player in Disease Modulation of Amyotrophic Lateral Sclerosis. Front Neurol, 8:669.

[156] Castellano G, Franzin R, Stasi A, Divella C, Sallustio F, Pontrelli P, et al. (2018). Complement Activation During Ischemia/Reperfusion Injury Induces Pericyteto-Myofibroblast Transdifferentiation Regulating Peritubular Capillary Lumen Reduction Through pERK Signaling. Front Immunol, 9:1002.

[157] Armulik A, Genove G, Mae M, Nisancioglu MH, Wallgard E, Niaudet C, et al. (2010). Pericytes regulate the blood-brain barrier. Nature, 468:557-561.

[158] Daneman R, Zhou L, Kebede AA, Barres BA (2010).


Pericytes are required for blood-brain barrier integrity during embryogenesis. Nature, 468:562-566.

[159] Casey CS, Atagi Y, Yamazaki Y, Shinohara M, Tachibana M, Fu Y, et al. (2015). Apolipoprotein E Inhibits Cerebrovascular Pericyte Mobility through a RhoA Protein-mediated Pathway. J Biol Chem, 290:14208-14217.

[160] Maas SLN, Breakefield XO, Weaver AM (2017). Extracellular Vesicles: Unique Intercellular Delivery Vehicles. Trends Cell Biol, 27:172-188.

[161] Shi M, Sheng L, Stewart T, Zabetian CP, Zhang J (2019). New windows into the brain: Central nervous system-derived extracellular vesicles in blood. Prog Neurobiol, 175:96-106.

[162] Eitan E, Hutchison ER, Marosi K, Comotto J, Mustapic M, Nigam SM, et al. (2016). Extracellular Vesicle-Associated Abeta Mediates Trans-Neuronal Bioenergetic and $\mathrm{Ca}(2+)$-Handling Deficits in Alzheimer's Disease Models. NPJ Aging Mech Dis, 2.

[163] Lee S, Mankhong S, Kang JH (2019). Extracellular Vesicle as a Source of Alzheimer's Biomarkers: Opportunities and Challenges. Int J Mol Sci, 20.

[164] Saeedi S, Israel S, Nagy C, Turecki G (2019). The emerging role of exosomes in mental disorders. Transl Psychiatry, 9:122.

[165] Xiao T, Zhang W, Jiao B, Pan CZ, Liu X, Shen L (2017). The role of exosomes in the pathogenesis of Alzheimer' disease. Transl Neurodegener, 6:3.

[166] Fyfe I (2018). Exosomes can spread toxic AD pathology. Nat Rev Neurol, 14:451.

[167] Sardar Sinha M, Ansell-Schultz A, Civitelli L, Hildesjo C, Larsson M, Lannfelt L, et al. (2018). Alzheimer's disease pathology propagation by exosomes containing toxic amyloid-beta oligomers. Acta Neuropathol, 136:41-56.

[168] Wu DM, Deng SH, Liu T, Han R, Zhang T, Xu Y (2018). TGF-beta-mediated exosomal lnc-MMP2-2 regulates migration and invasion of lung cancer cells to the vasculature by promoting MMP2 expression. Cancer Med, 7:5118-5129.

[169] Cherry JD, Olschowka JA, O'Banion MK (2014). Neuroinflammation and M2 microglia: the good, the bad, and the inflamed. J Neuroinflammation, 11:98.

[170] Giannakis N, Sansbury BE, Patsalos A, Hays TT, Riley CO, Han X, et al. (2019). Dynamic changes to lipid mediators support transitions among macrophage subtypes during muscle regeneration. Nat Immunol, 20:626-636.

[171] Salter MW, Stevens B (2017). Microglia emerge as central players in brain disease. Nat Med, 23:10181027.

[172] Kisler K, Nelson AR, Montagne A, Zlokovic BV (2017). Cerebral blood flow regulation and neurovascular dysfunction in Alzheimer disease. Nat Rev Neurosci, 18:419-434.

[173] Giles JA, Greenhalgh AD, Davies CL, Denes A, Shaw T, Coutts G, et al. (2015). Requirement for interleukin1 to drive brain inflammation reveals tissue-specific mechanisms of innate immunity. Eur J Immunol, 45:525-530.
[174] Tayebati SK, Tomassoni D, Amenta F (2016). Neuroinflammatory Markers in Spontaneously Hypertensive Rat Brain: An Immunohistochemical Study. CNS Neurol Disord Drug Targets, 15:995-1000

[175] Cipolla MJ, Liebeskind DS, Chan SL (2018). The importance of comorbidities in ischemic stroke: Impact of hypertension on the cerebral circulation. $\mathrm{J}$ Cereb Blood Flow Metab, 38:2129-2149.

[176] Gliem M, Mausberg AK, Lee JI, Simiantonakis I, van Rooijen N, Hartung HP, et al. (2012). Macrophages prevent hemorrhagic infarct transformation in murine stroke models. Ann Neurol, 71:743-752.

[177] Wattananit S, Tornero D, Graubardt N, Memanishvili T, Monni E, Tatarishvili J, et al. (2016). MonocyteDerived Macrophages Contribute to Spontaneous Long-Term Functional Recovery after Stroke in Mice. J Neurosci, 36:4182-4195.

[178] Zoller T, Schneider A, Kleimeyer C, Masuda T, Potru PS, Pfeifer D, et al. (2018). Silencing of TGFbeta signalling in microglia results in impaired homeostasis Nat Commun, 9:4011.

[179] Taylor RA, Chang CF, Goods BA, Hammond MD, Mac Grory B, Ai Y, et al. (2017). TGF-beta1 modulates microglial phenotype and promotes recovery after intracerebral hemorrhage. J Clin Invest, 127:280-292.

[180] Li Y, Shen XZ, Li L, Zhao TV, Bernstein KE, Johnson AK, et al. (2017). Brain Transforming Growth Factorbeta Resists Hypertension Via Regulating Microglial Activation. Stroke, 48:2557-2564.

[181] Jo WK, Law AC, Chung SK (2014). The neglected costar in the dementia drama: the putative roles of astrocytes in the pathogeneses of major neurocognitive disorders. Mol Psychiatry, 19:159-167.

[182] Price BR, Norris CM, Sompol P, Wilcock DM (2018). An emerging role of astrocytes in vascular contributions to cognitive impairment and dementia. J Neurochem, 144:644-650.

[183] Xu X, Zhang B, Lu K, Deng J, Zhao F, Zhao BQ, et al. (2016). Prevention of Hippocampal Neuronal Damage and Cognitive Function Deficits in Vascular Dementia by Dextromethorphan. Mol Neurobiol, 53:3494-3502.

[184] Nicolakakis N, Aboulkassim T, Aliaga A, Tong XK, Rosa-Neto P, Hamel E (2011). Intact memory in TGFbetal transgenic mice featuring chronic cerebrovascular deficit: recovery with pioglitazone. J Cereb Blood Flow Metab, 31:200-211.

[185] Deramecourt V, Slade JY, Oakley AE, Perry RH, Ince PG, Maurage CA, et al. (2012). Staging and natural history of cerebrovascular pathology in dementia. Neurology, 78:1043-1050.

[186] Gouw AA, van der Flier WM, Fazekas F, van Straaten EC, Pantoni L, Poggesi A, et al. (2008). Progression of white matter hyperintensities and incidence of new lacunes over a 3-year period: the Leukoaraiosis and Disability study. Stroke, 39:1414-1420.

[187] Hinman JD, Lee MD, Tung S, Vinters HV, Carmichael ST (2015). Molecular disorganization of axons adjacent to human lacunar infarcts. Brain, 138:736745 . 
[188] Skrobot OA, Attems J, Esiri M, Hortobagyi T, Ironside JW, Kalaria RN, et al. (2016). Vascular cognitive impairment neuropathology guidelines (VCING): the contribution of cerebrovascular pathology to cognitive impairment. Brain, 139:2957-2969.

[189] Rivera FJ, de la Fuente AG, Zhao C, Silva ME, Gonzalez GA, Wodnar R, et al. (2019). Aging restricts the ability of mesenchymal stem cells to promote the generation of oligodendrocytes during remyelination. Glia, 67:1510-1525.

[190] Ruckh JM, Zhao JW, Shadrach JL, van Wijngaarden P, Rao TN, Wagers AJ, et al. (2012). Rejuvenation of regeneration in the aging central nervous system. Cell Stem Cell, 10:96-103.

[191] Kuriyama N, Mizuno T, Kita M, Yamada K, Ozaki E, Matsumoto S, et al. (2014). TGF-betal is associated with the progression of intracranial deep white matter lesions: a pilot study with 5 years of magnetic resonance imaging follow-up. Neurol Res, 36:47-52.

[192] Hamaguchi M, Muramatsu R, Fujimura H, Mochizuki H, Kataoka H, Yamashita T (2019). Circulating transforming growth factor-betal facilitates remyelination in the adult central nervous system. Elife, 8.

[193] Palazuelos J, Klingener M, Aguirre A (2014). TGFbeta signaling regulates the timing of CNS myelination by modulating oligodendrocyte progenitor cell cycle exit through SMAD3/4/FoxO1/Sp1. J Neurosci, 34:79177930 .

[194] DeKosky ST, Scheff SW (1990). Synapse loss in frontal cortex biopsies in Alzheimer's disease: correlation with cognitive severity. Ann Neurol, 27:457-464.

[195] Henstridge CM, Tzioras M, Paolicelli RC (2019). Glial Contribution to Excitatory and Inhibitory Synapse Loss in Neurodegeneration. Front Cell Neurosci, 13:63.

[196] Terry RD, Masliah E, Salmon DP, Butters N, DeTeresa $\mathrm{R}$, Hill R, et al. (1991). Physical basis of cognitive alterations in Alzheimer's disease: synapse loss is the major correlate of cognitive impairment. Ann Neurol, 30:572-580.

[197] Bereczki E, Branca RM, Francis PT, Pereira JB, Baek JH, Hortobagyi T, et al. (2018). Synaptic markers of cognitive decline in neurodegenerative diseases: a proteomic approach. Brain, 141:582-595.

[198] Pennuto M, Bonanomi D, Benfenati F, Valtorta F (2003). Synaptophysin I controls the targeting of VAMP2/synaptobrevin II to synaptic vesicles. Mol Biol Cell, 14:4909-4919.

[199] Skaper SD, Facci L, Zusso M, Giusti P (2017). Synaptic Plasticity, Dementia and Alzheimer Disease. CNS Neurol Disord Drug Targets, 16:220-233.

[200] Sze CI, Troncoso JC, Kawas C, Mouton P, Price DL, Martin LJ (1997). Loss of the presynaptic vesicle protein synaptophysin in hippocampus correlates with cognitive decline in Alzheimer disease. J Neuropathol Exp Neurol, 56:933-944.

[201] Chen X, Nelson CD, Li X, Winters CA, Azzam R, Sousa AA, et al. (2011). PSD-95 is required to sustain the molecular organization of the postsynaptic density. J Neurosci, 31:6329-6338.

[202] Lin Y, Skeberdis VA, Francesconi A, Bennett MV, Zukin RS (2004). Postsynaptic density protein-95 regulates NMDA channel gating and surface expression. J Neurosci, 24:10138-10148.

[203] Sinclair LI, Tayler HM, Love S (2015). Synaptic protein levels altered in vascular dementia. Neuropathol Appl Neurobiol, 41:533-543.

[204] Sultana R, Banks WA, Butterfield DA (2010). Decreased levels of PSD95 and two associated proteins and increased levels of $\mathrm{BCl} 2$ and caspase 3 in hippocampus from subjects with amnestic mild cognitive impairment: Insights into their potential roles for loss of synapses and memory, accumulation of Abeta, and neurodegeneration in a prodromal stage of Alzheimer's disease. J Neurosci Res, 88:469-477.

[205] Antonucci F, Corradini I, Fossati G, Tomasoni R, Menna E, Matteoli M (2016). SNAP-25, a Known Presynaptic Protein with Emerging Postsynaptic Functions. Front Synaptic Neurosci, 8:7.

[206] Bark IC, Hahn KM, Ryabinin AE, Wilson MC (1995). Differential expression of SNAP-25 protein isoforms during divergent vesicle fusion events of neural development. Proc Natl Acad Sci U S A, 92:15101514.

[207] Moya-Alvarado G, Gershoni-Emek N, Perlson E, Bronfman FC (2016). Neurodegeneration and Alzheimer's disease (AD). What Can Proteomics Tell Us About the Alzheimer's Brain? Mol Cell Proteomics, 15:409-425.

[208] Takahashi H, Mizui T, Shirao T (2006). Downregulation of drebrin A expression suppresses synaptic targeting of NMDA receptors in developing hippocampal neurones. J Neurochem, 97 Suppl 1:110115 .

[209] Koeglsperger T, Li S, Brenneis C, Saulnier JL, Mayo $\mathrm{L}$, Carrier Y, et al. (2013). Impaired glutamate recycling and GluN2B-mediated neuronal calcium overload in mice lacking TGF-beta1 in the CNS. Glia, 61:985-1002.

[210] Caraci F, Gulisano W, Guida CA, Impellizzeri AA, Drago F, Puzzo D, et al. (2015). A key role for TGFbeta1 in hippocampal synaptic plasticity and memory. Sci Rep, 5:11252.

[211] Chin J, Angers A, Cleary LJ, Eskin A, Byrne JH (2002). Transforming growth factor betal alters synapsin distribution and modulates synaptic depression in Aplysia. J Neurosci, 22:RC220.

[212] Brionne TC, Tesseur I, Masliah E, Wyss-Coray T (2003). Loss of TGF-beta 1 leads to increased neuronal cell death and microgliosis in mouse brain. Neuron, 40:1133-1145.

[213] Dobolyi A, Vincze C, Pal G, Lovas G (2012). The neuroprotective functions of transforming growth factor beta proteins. Int J Mol Sci, 13:8219-8258.

[214] Kashima R, Hata A (2018). The role of TGF-beta superfamily signaling in neurological disorders. Acta Biochim Biophys Sin (Shanghai), 50:106-120.

[215] Vogel T, Ahrens S, Buttner N, Krieglstein K (2010). 
Transforming growth factor beta promotes neuronal cell fate of mouse cortical and hippocampal progenitors in vitro and in vivo: identification of Nedd9 as an essential signaling component. Cereb Cortex, 20:661-671.

[216] Lesne S, Docagne F, Gabriel C, Liot G, Lahiri DK, Buee L, et al. (2003). Transforming growth factor-beta 1 potentiates amyloid-beta generation in astrocytes and in transgenic mice. J Biol Chem, 278:1840818418.

[217] Bosco P, Ferri R, Salluzzo MG, Castellano S, Signorelli M, Nicoletti F, et al. (2013). Role of the Transforming-Growth-Factor-beta1 Gene in LateOnset Alzheimer's Disease: Implications for the Treatment. Curr Genomics, 14:147-156.

[218] Lively S, Lam D, Wong R, Schlichter LC (2018). Comparing Effects of Transforming Growth Factor betal on Microglia From Rat and Mouse: Transcriptional Profiles and Potassium Channels. Front Cell Neurosci, 12:115.

[219] von Bernhardi R, Cornejo F, Parada GE, Eugenin J (2015). Role of TGFbeta signaling in the pathogenesis of Alzheimer's disease. Front Cell Neurosci, 9:426.

[220] Wang F, Cao Y, Ma L, Pei H, Rausch WD, Li H (2018). Dysfunction of Cerebrovascular Endothelial Cells: Prelude to Vascular Dementia. Front Aging Neurosci, 10:376.

[221] Marcello E, Epis R, Saraceno C, Di Luca M (2012). Synaptic dysfunction in Alzheimer's disease. Adv Exp Med Biol, 970:573-601.

[222] Ridler C (2018). Neurodegenerative disease: Proteome points to synaptic dysfunction in dementia. Nat Rev Neurol, 14:128.

[223] Kandasamy M, Aigner L (2018). Neuroplasticity, limbic neuroblastosis and neuro-regenerative disorders. Neural Regen Res, 13:1322-1326.

[224] Qin Y, Garrison BS, Ma W, Wang R, Jiang A, Li J, et al. (2018). A Milieu Molecule for TGF-beta Required for Microglia Function in the Nervous System. Cell, 174:156-171 e116.

[225] Wachs FP, Winner B, Couillard-Despres S, Schiller T, Aigner R, Winkler J, et al. (2006). Transforming growth factor-betal is a negative modulator of adult neurogenesis. J Neuropathol Exp Neurol, 65:358-370.

[226] Pineda JR, Daynac M, Chicheportiche A, CebrianSilla A, Sii Felice K, Garcia-Verdugo JM, et al. (2013). Vascular-derived TGF-beta increases in the stem cell niche and perturbs neurogenesis during aging and following irradiation in the adult mouse brain. EMBO Mol Med, 5:548-562.

[227] Kandasamy M, Aigner L (2018). Reactive Neuroblastosis in Huntington's Disease: A Putative Therapeutic Target for Striatal Regeneration in the Adult Brain. Front Cell Neurosci, 12:37.

[228] Gooch J, Wilcock DM (2016). Animal Models of Vascular Cognitive Impairment and Dementia (VCID). Cell Mol Neurobiol, 36:233-239.

[229] Ni J, Ohta H, Matsumoto K, Watanabe H (1994). Progressive cognitive impairment following chronic cerebral hypoperfusion induced by permanent occlusion of bilateral carotid arteries in rats. Brain Res, 653:231-236.

[230] Sivilia S, Giuliani A, Del Vecchio G, Giardino L, Calza L (2008). Age-dependent impairment of hippocampal neurogenesis in chronic cerebral hypoperfusion. Neuropathol Appl Neurobiol, 34:5261.

[231] Choi DH, Lee KH, Lee J (2016). Effect of exerciseinduced neurogenesis on cognitive function deficit in a rat model of vascular dementia. Mol Med Rep, 13:2981-2990.

[232] Kwon KJ, Kim MK, Lee EJ, Kim JN, Choi BR, Kim SY, et al. (2014). Effects of donepezil, an acetylcholinesterase inhibitor, on neurogenesis in a rat model of vascular dementia. J Neurol Sci, 347:66-77. Maiti P, Peruzzaro S, Kolli N, Andrews M, AlGharaibeh A, Rossignol J, et al. (2019). Transplantation of mesenchymal stem cells overexpressing interleukin-10 induces autophagy response and promotes neuroprotection in a rat model of TBI. J Cell Mol Med, 23:5211-5224.

[234] Unger MS, Schernthaner P, Marschallinger J, Mrowetz H, Aigner L (2018). Microglia prevent peripheral immune cell invasion and promote an antiinflammatory environment in the brain of APP-PS1 transgenic mice. J Neuroinflammation, 15:274.

[235] Winner B, Winkler J (2015). Adult neurogenesis in neurodegenerative diseases. Cold Spring Harb Perspect Biol, 7:a021287.

[236] Raz L, Knoefel J, Bhaskar K (2016). The neuropathology and cerebrovascular mechanisms of dementia. J Cereb Blood Flow Metab, 36:172-186.

[237] Buisson A, Lesne S, Docagne F, Ali C, Nicole O, MacKenzie ET, et al. (2003). Transforming growth factor-beta and ischemic brain injury. Cell Mol Neurobiol, 23:539-550.

[238] Cacheaux LP, Ivens S, David Y, Lakhter AJ, Bar-Klein G, Shapira M, et al. (2009). Transcriptome profiling reveals TGF-beta signaling involvement in epileptogenesis. J Neurosci, 29:8927-8935.

[239] Chen X, Hu Y, Cao Z, Liu Q, Cheng Y (2018). Cerebrospinal Fluid Inflammatory Cytokine Aberrations in Alzheimer's Disease, Parkinson's Disease and Amyotrophic Lateral Sclerosis: A Systematic Review and Meta-Analysis. Front Immunol, 9:2122.

[240] Lewczuk P, Riederer P, O'Bryant SE, Verbeek MM, Dubois B, Visser PJ, et al. (2018). Cerebrospinal fluid and blood biomarkers for neurodegenerative dementias: An update of the Consensus of the Task Force on Biological Markers in Psychiatry of the World Federation of Societies of Biological Psychiatry. World J Biol Psychiatry, 19:244-328.

[241] Galan L, Gomez-Pinedo U, Guerrero A, GarciaVerdugo JM, Matias-Guiu J (2017). Amyotrophic lateral sclerosis modifies progenitor neural proliferation in adult classic neurogenic brain niches. BMC Neurol, 17:173.

[242] Jin K, Peel AL, Mao XO, Xie L, Cottrell BA, Henshall DC, et al. (2004). Increased hippocampal 
neurogenesis in Alzheimer's disease. Proc Natl Acad Sci U S A, 101:343-347.

[243] Pouladi MA, Morton AJ, Hayden MR (2013). Choosing an animal model for the study of Huntington's disease. Nat Rev Neurosci, 14:708-721.

[244] Li XJ, Li S (2015). Large Animal Models of Huntington's Disease. Curr Top Behav Neurosci, 22:149-160.

[245] Ramaswamy S, McBride JL, Kordower JH (2007). Animal models of Huntington's disease. ILAR J, 48:356-373.

[246] Donovan MH, Yazdani U, Norris RD, Games D, German DC, Eisch AJ (2006). Decreased adult hippocampal neurogenesis in the PDAPP mouse model of Alzheimer's disease. J Comp Neurol, 495:7083.

[247] Wirths O (2017). Altered neurogenesis in mouse models of Alzheimer disease. Neurogenesis (Austin), 4:e1327002.

[248] Baig S, van Helmond Z, Love S (2009). Tau hyperphosphorylation affects Smad 2/3 translocation. Neuroscience, 163:561-570.

[249] Chalmers KA, Love S (2007). Neurofibrillary tangles may interfere with Smad 2/3 signaling in neurons. J Neuropathol Exp Neurol, 66:158-167.

[250] Das P, Golde T (2006). Dysfunction of TGF-beta signaling in Alzheimer's disease. J Clin Invest, 116:2855-2857.

[251] Hollands C, Bartolotti N, Lazarov O (2016). Alzheimer's Disease and Hippocampal Adult Neurogenesis; Exploring Shared Mechanisms. Front Neurosci, 10:178.

[252] Rodriguez JJ, Verkhratsky A (2011). Neurogenesis in Alzheimer's disease. J Anat, 219:78-89.

[253] Kandasamy M, Yesudhas A, Poornimai Abirami GP, Radhakrishnan RK, Roshan SA, Johnson E, et al. (2019). Genetic reprogramming of somatic cells into neuroblasts through a co-induction of the doublecortin gene along the Yamanaka factors: A promising approach to model neuroregenerative disorders. Med Hypotheses, 127:105-111.

[254] Navarro V, Sanchez-Mejias E, Jimenez S, MunozCastro C, Sanchez-Varo R, Davila JC, et al. (2018). Microglia in Alzheimer's Disease: Activated, Dysfunctional or Degenerative. Front Aging Neurosci, 10:140.

[255] Gregory CD, Devitt A (2004). The macrophage and the apoptotic cell: an innate immune interaction viewed simplistically? Immunology, 113:1-14.

[256] Lucas M, Stuart LM, Savill J, Lacy-Hulbert A (2003). Apoptotic cells and innate immune stimuli combine to regulate macrophage cytokine secretion. J Immunol, 171:2610-2615.

[257] Velusamy T, Panneerselvam AS, Purushottam M, Anusuyadevi M, Pal PK, Jain S, et al. (2017). Protective Effect of Antioxidants on Neuronal Dysfunction and Plasticity in Huntington's Disease. Oxid Med Cell Longev, 2017:3279061.

[258] Bennett S, Grant MM, Aldred S (2009). Oxidative stress in vascular dementia and Alzheimer's disease: a common pathology. J Alzheimers Dis, 17:245-257.

[259] Sun MS, Jin H, Sun X, Huang S, Zhang FL, Guo ZN, et al. (2018). Free Radical Damage in IschemiaReperfusion Injury: An Obstacle in Acute Ischemic Stroke after Revascularization Therapy. Oxid Med Cell Longev, 2018:3804979.

[260] Jullien P, Berg TM, Lawrence DA (1989). Acidic cellular environments: activation of latent TGF-beta and sensitization of cellular responses to TGF-beta and EGF. Int J Cancer, 43:886-891.

[261] Unger MS, Marschallinger J, Kaindl J, Klein B, Johnson M, Khundakar AA, et al. (2018). Doublecortin expression in CD8+ T-cells and microglia at sites of amyloid-beta plaques: A potential role in shaping plaque pathology? Alzheimers Dement, 14:1022-1037.

[262] Town T, Laouar Y, Pittenger C, Mori T, Szekely CA, Tan J, et al. (2008). Blocking TGF-beta-Smad2/3 innate immune signaling mitigates Alzheimer-like pathology. Nat Med, 14:681-687.

[263] Bedinger D, Lao L, Khan S, Lee S, Takeuchi T, Mirza AM (2016). Development and characterization of human monoclonal antibodies that neutralize multiple TGFbeta isoforms. MAbs, 8:389-404.

[264] Taniguchi A, Matsuzaki K, Nakano K, Kan M, McKeehan WL (1998). Ligand-dependent and independent interactions with the transforming growth factor type II and I receptor subunits reside in the aminoterminal portion of the ectodomain of the type III subunit. In Vitro Cell Dev Biol Anim, 34:232-238.

[265] Nagaraj NS, Datta PK (2010). Targeting the transforming growth factor-beta signaling pathway in human cancer. Expert Opin Investig Drugs, 19:77-91. 